\title{
„POST MORTEM VIVERE” GONDOLATOK TRIMALCHIO SÍREMLÉKÉRÖL
}

\begin{abstract}
Petronius szatirikus regényének legismertebb részlete, a Cena Trimalchionis már régóta nemcsak a filológusok és irodalomtörténészek, hanem a római társadalomtudósok és gazdaságtörténészek érdeklődésének homlokterében áll. A kutatásban mára konszenzussá vált, hogy Trimalchio személyében Petronius a korai principátus egyik tipikus szereplőjét: a rabszolga-származású, részben egykori gazdája vagyonából, részben önerejéből megtollasodott parvenü libertinus karikatúráját írta meg. Trimalchio fiktív síremlékének és sírfeliratának elemzése azt bizonyítja, hogy bár ez a kép nagy általánosságban igaz, mégis "finomhangolásra” szorul. Először is: mindez elsősorban irodalom, melynek elsődleges célja, hogy - a nyilvánvaló morális tanulságokon túl - szórakoztasson. Másodsorban a szatíra három alapvető eszközzel dolgozik: a tipizálással, a vegyítéssel és a nagyítással/kicsinyítéssel. Nem csoda hát, ha Trimalchio személyében is a kortárs Róma megannyi celebritásának jellemzőit felfedezték már (Maecenas, Claudius, Nero stb.). A monumentum és az epitaphium elemzése mégis leginkább azt mutatja, hogy Trimalchio megannyi „császári allürje” és hatalmas gazdagsága ellenére csak egy nagyszájú vidéki bugris, akinek környezete - mint ő maga is - kívül-belül giccses és ízléstelen. A tanulmányban megvizsgáljuk a Sat. 71,5-12 eddigi fordításainak erősségeit és hibáit, és egy saját fordításra is kísérletet teszünk.
\end{abstract}

Kulcsszavak: Petronius, Satyricon, Cena Trimalchionis, római regény, szatíra, felszabadítottak, római epigráfia, római sírművészet, fordításelmélet

Miközben az irodalomtörténészek azon vitatkoznak, hogy Petronius töredékesen fennmaradt regénye szatíra-e, és ha igen, milyen értelemben nevezhető annak, ${ }^{1}$ a korai principátus társadalmának és gazdaságának kutatói már közel egy évszázada egyik alapvető elbeszélő forrásuknak tekintik a Satyricont. Hubert Petersmann megfogalmazása - miszerint a Satyricon „a korai császárkor társadalmának és annak tipikus képviselőinek hiteles ábrázolása"2 - truizmusnak számít ezekben a kutatói körökben. Ma már többé-kevésbé konszenzusnak tekinthető, hogy a Cena jeleneteiben Tiberius, Claudius és Nero korának szatírája sürüsödik össze. ${ }^{3}$ Az epizód helyszínét, a regényben említett Graeca

1 J. P. Sullivan: The Satyricon of Petronius: A Literary Study. Bloomington - London 1968; G. Sandy: Satire in the Satyricon. AJPh 90 (1969) 293-303; P. G. Walsh: Was Petronius a Moralist? G\&R 21 (1974) 181191; R. Beck: The Satyricon: Satire, Narrator and Antecedents. MusHelv 39 (1982) 206-214; G. Schmeling: Petronius and the Satyrica. In: Latin Fiction: the Latin Novel in Context. Ed. H. Hoffman. London - New York 1999. 23-37; V. Rimell: Petronius and the Anatomy of Fiction. Cambridge 2002; Adamik T.: Római irodalom. A kezdetektől a Nyugatrómai Birodalom bukásáig. Pozsony 2009. 528-529.

2 „Getreuen Abbild der Gesellschaft der frühen Kaiserzeit und ihrer typischen Vertreter”, H. Petersmann: Umwelt, Sprachsituation, und Stilschichten in Petrons Satyrica. ANRW II. 32.3. Berlin - New York 1985. 1687-1705, különösen 1688.

${ }^{3}$ K. F. C. Rose: The Date and Author of the Satyricon. Leiden 1971. 
urbs $(81,3)$, illetve colonia $(44,12 ; 44,16 ; 57,9 ; 76,10)$ azonosítását illetően régóta vita folyik a kutatók között: egyebek mellett Ancona, Capua, Cumae, Nápoly, Pompeii és Tarentum neve is felmerült, de a communis opinio mára Puteoli (Dikaiarchia) mellett állapodott meg. ${ }^{4}$ Ez egy valódi multikulturális környezet volt, ahol a rómaiak mellett görögök, oscusok, samnisok és persze számos keleti eredetű (egyiptomi, szír, föníciai, zsidó, nabateus stb.) lakos élt vagy tartózkodott hosszabb-rövidebb ideig. ${ }^{5}$ Ugyanakkor igazat kell adnunk Rabun Taylornak is, aki szerint „Petronius városát legjobban Puteoli és Nápoly aránytalan hibridjének (Puteopolis?) képzelhetjük el, az előbbi dominanciájával” - leginkább a világszerte jól ismert angliai „Oxbridge” mintájára.

Rövid, de hasznos összegző tanulmányában a társadalom, gazdaság, vallás és kultúra területét vizsgálta meg a regény tükrében Eckart Olshausen. ${ }^{6}$ Gazdaságtörténeti szempontból rendkívül érdekes, ahogyan Petronius felvázolja hősének, Trimalchiónak karrierjét, aki senatori rendű gazdája örököseként kereskedelmi vállalkozásokon gazdagodott meg, s az így nyert pénzen földvásárlásokba fogott, majd pénzkölcsönzésre tért át. ${ }^{7}$ Trimalchio környezetének vallásában a babonaság, a mágikus néphit és az asztrológia játszotta a főszerepet, a hagyományos pantheonból csak az egyéni karrierje szempontjából fontosabb isteneket: Iuppitert, Minervát, Mercuriust, valamint a Profit, Szerencse és Nyereség (Cerdo, Felicio és Lucro) néven emlegetett lárokat tisztelte $(60,5){ }^{8}$ A császárkultuszban való részvétel viszont nagyon fontos volt a regény szereplőinek, akik közül Trimalchio $(30,2)$, Hermeros $(57,6)$ és Habinnas $(65,5)$ is Augustalis volt.

4 R. Taylor: A Documentary History of Naples: Ancient Naples, Chapter Five - From Republic to Empire. Ancient Greek and Roman History e-Journal (2010) http://dx.doi.org/10.2139/ssrn.1676288.

5 G. Soricelli: Comunità orientali a Puteoli. In: Étrangers dans la cité romaine. Habiter une autre patrie: des incolae de la République aux peuples fédérés du Bas-Empire. Éds. R. Compatangelo-Soussignan - C-G. Schwentzel. Rennes 2007. 129-144; P. Orlando: Peregrini a Puteoli e mercatores puteolani nel Mediterraneo (I-III d.C.), PhD. diss. (Università degli Studi di Napoli Federico II, 2014).

6 E. Olshausen: Soziokulturelle Betrachtungen zur Cena Trimalchionis. In: Studien zu Petron und seiner Rezeption / Studi su Petronio e sulla sua fortuna. Hrsgg. L. Castagna - E. Lefèvre - C. Riboldi. Berlin 2007. 15-31.

7 P. Veyne: Vie de Trimalchion. Annales 16 (1961) 213-247; J. H. D’Arms: The Typicality of Trimalchio. In: Commerce and Social Standing in Ancient Rome. Cambridge (Mass.) - London 1981. 91-120; P. Garnsey: Independent Freedmen and the Economy of Roman Italy under the Principate. Klio 63 (1981) 359-372; $H$. Kloft: Trimalchio als Ökonom. Bemerkungen zur Rolle der Wirtschaft in Petrons Satyricon. In: E fontibus haurire. Beiträge zur römischen Geschichte und zu ihren Hilfswissenschaften. Festschrift für H. Chantraine. Hrsgg. R. Günther - S. Rebenich. Paderborn - München 1994. 117-131; J. Bodel: Omnia in Nummis: Money and the Monetary Economy in Petronius. In: Moneta Mercanti Banchieri. I precedenti greci e romani dell'Euro. Atti del convegno internazionale Cividale del Friuli, 26-28 settembre 2002. Ed. G. Urso. Pisa 2003. 270-282; K. Verboven: A Funny Thing Happened on My Way to the Market. Reading Petronius to Write Economic History. In: Petronius: A Handbook. Eds. J. Prag - I. Repath. Malden - Oxford 2009. 125-139.

8 H. Petersmann: Religion, Superstition and Parody in Petronius' Cena Trimalchionis. In: Groningen Colloquia on the Novel: Papers vol. 6. Eds. M. Zimmerman - H. Hofmann. Groningen 1995. 75-85; M. Grondona: La religione e la superstizione nella Cena Trimalchionis. Bruxelles 1980; W. Hübner: Trimalchio Mercurialis. In: Des geants à Dionysos. Mélanges de mythologie et de poesie grecques offerts à Francis Vian. Éds. D. Accorinti - P. Chuvin. Alessandria 2003. 75-94. 
A mérhetetlenül parvenü libertini köreiben a kultúrának is inkább csak karikatúrájával találkozhatunk: a magát Maecenatianusnak nevező Trimalchio valójában csak a gladiátorjátékokért bolondul, és hiába tart fenn házában „három” (görög és latin) könyvtárat, ${ }^{9}$ a cena müsorán is akrobaták $(53,11)$, szemfényvesztők $(53,13)$ és a magukat „homéristáknak" nevező ripacsok jelennek meg $(59,2) .{ }^{10}$ A lakoma félművelt-félanalfabéta közönsége is hetet-havat összehord, mikor felidézi az ismert mitológiai történeteket. ${ }^{11}$ A házigazda ízlése kritikán aluli: nemcsak az ételek, a tálalás, hanem a meghívottak viselkedése és beszélgetései is néha már groteszken ízléstelenek, sőt gyomorforgatók. ${ }^{12}$

De kicsoda valójában Trimalchio? Pontosabban szólva, mi lehetett Petronius célja Trimalchio alakjának megformálásával? A szakirodalomban csaknem teljes konszenzus uralkodik abban a kérdésben, hogy a Malchio névelem a 'király' jelentésü szír malchos vagy malicho szóra vezethető vissza, annak a tri-prefixummal ellátott változata, melynek jelentése talán „háromszoros király” vagy „nagyon nagy király”.13 Ma már közhelynek számít a társadalom- és gazdaságtörténészek körében, hogy a keleti bevándorolt $l i$ bertini az augustusi béke korszakától kezdve gyakorlatilag kezükbe kaparintották Róma kereskedelmét. Ez egy természetes folyamat eredménye volt, minthogy nemcsak Róma legértékesebb, hanem legfontosabb kereskedelmi árucikkei is zömében Keletről érkeztek. Ezek kereskedelmét pedig érthető módon a levantei kereskedők tartották kezükben. A római arisztokrácia értékrendjében nagyon alacsony presztízsű és a jó erkölcsökre nézve veszélyes foglalkozásnak minősült a kereskedelem. ${ }^{14}$ A levanteiek (kis-ázsiai

9 AdamikB.: Tres bibliothecas habeo, unam Graecam, alteram Latinam: textkritische, philologische und soziolinguistische Interpretation von Petrons Satyricon 48.4. AAAHung 45 (2005) 133-142; K. Freidenburg: A Note on Trimalchio's Three (Equals Two) Libraries. CQ 67 (2017) 323-327.

10 „Máris belépett az ebédlőbe a társulat, és lándzsákkal pajzsait döngette. Maga Trimalchio fölült a párnára, és miközben a homeristák, megszokhatatlan szokásuk szerint, görögül szavalták a dramatizált szöveget, ő éneklő hangon latinul olvasta a verseskönyvet” Horváth István Károly fordítása. R. J. Starr: Trimalchio's Libraries. Hermes 115 (1987) 252-253; R. J. Starr: Trimalchio's Homeristae. Latomus 46 (1987) 199-200.

11 E. E. Best: Attitudes toward Literacy Reflected in Petronius. CJ 61 (1965) 72-76; R. W. Daniel: Liberal Education and Semiliteracy in Petronius. ZPE 40 (1980) 153-159; N. Horsfall: The Uses of Literacy and the Cena Trimalchionis I-II. G\&R 36 (1989) 74-89, 194-209; P. Grossardt: Der trojanische Krieg in der Darstellung des Trimalchio (Petron, Sat. 59, 4-5). RhM 155 (2012) 310-363; K. S. Lamp: False Copies: Education, Imitation, and Citizenship in the Satyricon. Advances in the History of Rhetoric 17 (2014) 43-52.

12 W. Arrowsmith: Luxury and Death in the Satyricon. Arion 5 (1966) 304-331; G. Schmeling: Trimalchio's Menu and Wine List. CPh 65 (1970) 248-251.

13 A „nagyon nagy” jelentése a trifur vagy a trismegistos mintájára, lásd G. Bagnani: Trimalchio. Phoenix 8 (1954) 77-91; J. Bremmer: 'Malchos' King and Trimalchio. Mnemosyne 34 (1981) 395; J. Perkins: Trimalchio: Naming Power. Metaphor and the Ancient Novel. AN Suppl. 4 (2005) 139-162. Moses Hadas a müben olvasható közmondásokat és neveket kapcsolta össze talmudi szöveghelyekkel, de véleményem szerint nem sikerült közvetlen átvételt kimutatnia: M. Hadas: Oriental Elements in Petronius. AJPh 50 (1929) 378-385. Újabban is akadnak, akik megpróbálják Trimalchio zsidó származását bizonyítani, szintén kevés sikerrel: W. M. Clarke: Jewish Table Manners in the Cena Trimalchionis. CJ 87 (1992) 257-263.

14 Vö. Cic. De off. I. 150: Sordidi etiam putandi, qui mercantur a mercatoribus, quod statim vendant; nihil enim proficiant, nisi admodum mentiantur; nec vero est quicquam turpius vanitate. J. H. D'Arms: Commerce and Social Standing in Ancient Rome. Cambridge (Mass.) - London 1981; N. Morley: Trade in Classical Antiquity. Cambridge 2007. 82-85. 
görögök, szírek, arabok) körében viszont nem éltek ilyen előítéletek a kereskedelemmel szemben - kivéve a zsidóságot, amely csak a IV. században kezd tömegesen ezzel a szakmával foglalkozni. ${ }^{15} \mathrm{~A}$ késő császárkorban már egyértelmüen a szírek uralták Róma kereskedelmét, olyannyira, hogy a Syrus egyenlő volt a 'kereskedö' vagy a 'bankár' megjelöléssel. ${ }^{16}$

A levantei kereskedők szinte mindenütt jelen voltak a Mediterráneumban, és nemcsak közvetítő kereskedelmet folytattak, hanem anyanemzetük vallási szokásait, nyelvét és kultúráját is képviselték. Ennek elsődleges eszközei voltak a collegiumok. Ezek olyan zárt körủ klubok voltak, amelyekben többnyire azonos etnikai hátterủ és foglalkozású egyének tömörültek. A collegiumok szervezete három pilléren nyugodott: a haza, az istenek és a császár kultuszán, az elhunyt klubtagok emlékének megőrzésén, valamint a közös lakomákon. ${ }^{17}$ A collegiumok gyüléshelyének nevei (schola, statio, templum) is kifejezik azt, hogy a kultuszközösség és a társadalmi szolidaritás elválaszthatatlanul összefonódott bennük. ${ }^{18}$ A statiók működéséről feliratos forrásokból értesülhetünk. A legismertebb ilyen témájú felirat Kr. u. 174-ben Puteoliban kelt, és a tyrusi kereskedők céhének anyavárosuk tanácsához írt kérését fogalmazza meg. ${ }^{19} \mathrm{~A}$ Puteoliban tartózkodó bérytosiak így nevezik önmagukat: cultores Iovis Heliopolitani Berytenses qui Puteolis consistunt (CIL X 1759), illetve qui in cultu corporis Helipolitanorum sunt (CIL X 1679). Puteoliban egyébként a következő peregrini voltak a tyrosiakéhoz és a bérytosiakéhoz hasonló klubjaik: Heliopolitanenses (Baalbek), Germellenses (nem azonosított africai vagy syriai hely), valamint a Nabataenses (nabateusok). ${ }^{20}$ Egy graffito a compitani Daphnensest is említi, amely valószínűleg az Orontés melletti Antiochia Daphné nevü ismert külvárosa lehetett (AE 1932, 71). Puteolit (vagyis görög nevén Dikaiarchiát) egyébként már a Kr. e. II. században élt szatíraíró Lucilius is „kis Délosnak” (Delus minor) is nevezte $(118 \mathrm{~W}=123 \mathrm{M})$, amelynek társadalmában jelentős szerepet kaptak az

15 Természetesen nem akarom azt a látszatot kelteni, mintha a zsidók korábban nem foglalkoztak volna távolsági kereskedelemmel, hiszen akár az egyiptomi-indiai kereskedelemben (az alabarchosok révén, mint Marcus Iulius Alexander), akár a nyugati provinciákban is jelen voltak a zsidók. Néhány éve Carnuntumban került elő egy Marcus Mulvius nevű zsidó kereskedő felirata az I-II. századból (AE 2009, 1051).

16 L. Ruggini: Ebrei e orientali nell'Italia settentrionale fra il IV e il VI secolo d. Cr. SDHI 25 (1959) 186-308, különösen 188.

17 K. Verboven: Resident Aliens and Translocal Merchant Collegia in the Roman Empire. In: Frontiers in the Roman World: Proceedings of the Ninth Workshop of the International Network Impact of Empire. Eds. O. Hekster - T. Kaizer. Leiden 2011. 335-348.

18 J-P. Waltzing: Étude historique sur les corporations professionnelles chez les Romains depuis les origines jusqu'à la chute de l'Empire d'Occident. Bruxelles - Louvain 1895. I, 195-255; F. Ausbüttel: Untersuchungen zu den Vereinen im Westen des römischen Reiches. Kallmünz 1982. 29.

19 J. Sosin: Tyrian »stationarii« at Puteoli. Tyche 14 (1999) 275-284. Magyarul Patay-Horváth András fordításában olvasható: Római történelem. Szöveggyüjtemény. Szerk. Borhy L. Budapest 1998. 161.

20 G. Camodeca: Communità di peregrini a Puteoli nei primi due secoli dell'imperio. In: Le vie della storia. Migrazioni di popoli, viaggi di individui, circolazione di idee nel Mediterraneo antico. Eds. M. Bertinelli - A. Donati. Roma 2006. 269-287. 
orientális felszabadítottak, s az itt tartózkodó kereskedők is kiemelkedő szerepet vállaltak a rendkívül jövedelmező arábiai és indiai kereskedelemben. ${ }^{21}$

De térjünk vissza a Cena Trimalchionis és a gazdaság kapcsolatára. Petronius szövegéből megtudjuk, hogy Trimalchio egykori gazdája senator lehetett, mivel felszabadítása után „széles bíborszegélyű birtokot” örökölt (76, 2: accepi patrimonium laticlavium). ${ }^{22}$ A szolga már ekkor dispensatorként dolgozott $(29,4),{ }^{23}$ illetve gazdájának afféle "mindenese” lett (76, 1: dominus in domo factus sum). Az öröklés után elegendő tőkével rendelkezett ahhoz, hogy hajós vállalkozásba kezdjen. Előbb öt hajót töltött meg borral, s az egészet Rómába küldte, de a vihar mindegyiket elsüllyesztette, így 30 milliós kára keletkezett. Ekkor újabb - „nagyobb, erősebb és szerencsésebb” - hajókat építtetett, melyeket borral, szalonnával, babbal, illatszerekkel és rabszolgákkal (vinum, lardum, fabam, seplasium, mancipia) tömött meg, és 100 milliót keresett egyetlen úton. ${ }^{24}$ John Bodel tanulmányában arra hívja fel a figyelmet, hogy Trimalchio - környezetének libertinus kereskedelmi vállalkozóival szemben ${ }^{25}$ - nem a biztos jövedelmet ígérő gabonakereskedelemet választotta. ${ }^{26}$ Ami a bort illeti: az „akkoriban aranyat ért” $(76,3)$

${ }^{21}$ F. de Romanis: Puteoli e l'oriente. In: Puteoli. Ed. F. Zevi. Napoli 1993. 90-116; A. Tchernia: The Romans and Trade. Oxford 2016. 42-50.

22 „Fejedelemi vagyonhoz jutottam” (Révay József), bíborszegélyű togához méltó, vagyis „szenátorhoz méltó” (Horváth István Károly), egyértelműen az utóbbi fordítás a helyes, lásd $R$. J. A. Talbert: The Senate of Imperial Rome. Princeton 1984. 216-220.

23 Trimalchio szűkebb és tágabb baráti körében több dispensator is található, közülük a legérdekesebb Cinnamus, akitől egy bronz fasces cum embolo díszt is kapott: R. Bedon: Pétrone, Satiricon, XXX: le dispensator Cinnamus. Paris 1996. 151-166. További érdekesség, hogy egy C. Sulpicius Cinnamus nevü libertinus bankár müködött Puteoliban Kr. u. 42-56 között, lásd D. Jones: The Bankers of Puteoli: Finance, Trade and Industry in the Roman World. Stroud 2006. A dispensatorok szerepéről általában lásd L. Schumacher: On the Status of Private Actores, Dispensatores and Vilici. BICS 53 (2010) 31-47.

24 Bodel: i. m. (7. jegyz.) 271-282 joggal hívja fel a figyelmet arra, hogy Petronius regényében a számadatok igen gyakran „mesebeli számok”. Az ún. Muziris-papirusz érdekes adatokkal szolgál a Kr. u. II. század közepén Indiából érkező Hermapollón nevű hajó rakományáról (bors, teknőcpáncél, gangeszi nárdus, malabathron, elefántcsont), amely de Romanis számítása szerint 625 tonnát nyomott, és összértéke nagyjából 27,7 millió HS-t tett ki. L. Casson: PVindob. G 40822 and the Shipping of Goods from India. BASP 23 (1986) 73-79; L. Casson: New Light on Maritime Loans: PVindob G 40822. ZPE 84 (1990) 195-206; D. Rathbone: The Muziris papyrus (SB XVIII 13167): Financing Roman Trade with India. In: Alexandrian Studies II in Honor of Mostafa el Abbadi. Eds. M. Abd-El-Ghani - S. Z. Bassiouni - W. A. Farag. Alexandria 2000. 4-6; F. de Romanis: Playing Sudoku on the Verso of the Muziris Papyrus: Pepper, Malabathron and Tortoise Shell in the Cargo of the Hermapollon. JAIH 27 (2012) 75-101. A Trimalchio által felsorolt árucikkek - talán a rabszolgák kivételével - jóval olcsóbbak voltak, mint az indiai áruk, ezért ötnél biztosan több hajót kellett építenie és áruval megraknia.

25 1959-ben Pompeii Sarno folyó melletti kikötőjének egyik házából, amely valószínűleg egy collegiumé lehetett, kb. 70 írótábla került elő, amely C. Sulpicius Faustus és szabadosa, C. Sulpicius Cinnamus kölcsönügyleteit tartalmazta kb. Kr. u. 20-60 között (Tabulae Pompeianae Sulpiciorum = TPompSulp), kritikai kiadását lásd G. Camodeca: Tabulae Pompeianae Sulpiciorum. Edizione critica dell'archivio puteolano dei Sulpicii. Roma 1999.

26 J. Bodel: Trimalchio's Cargo (Petr. 76,6). In: Il Mediterraneo e la storia II: Naviganti, popoli e culture ad Ischia e in altri luoghi della costa tirrenica. Atti del convegno internazionale Sant'Angelo di Ischia, 9-11 ottobre 2015. Eds. L. Chioffi - M. Kajava - S. Örmä. Roma 2017. 75-87. 
megjegyzés azt sejteti, hogy első osztályú campaniai borokról lehetett szó. Trimalchio második vállalkozását illetően már Paul Veyne is megsejtette, hogy itt valamiféle „szólásmondásszerü felsorolásról" lehet szó. ${ }^{27}$ Bár a feliratos forrásokban találkozunk lardarius, fabarius és seplasiarius kereskedőkkel (ráadásul a szépítőszerek gyártásának legismertebb központja is a közeli Capuában volt, nem is szólva a rabszolga-kereskedelemről, amely egyértelműen Puteoliban összpontosult); ${ }^{28}$ mégsem lenne sok értelme ezt a rakományt konkrét gazdasági adatként kezelni, mivel Petronius célja nyilvánvalóan Trimalchio ízléstelenségének további demonstrálása lehetett. ${ }^{29}$ (Hogyan illik össze a szalonna az illatszerekkel, vagy a bab a rabszolgákkal?)

Trimalchio az így nyert pénzen újra földet vett: „Tüstént megvásároltam az öszszes telkeket, amelyek azelőtt patronusoméi voltak. Házat építtettem, fölvásároltam az egész rabszolgapiacot, $\mathrm{s}$ igásállatokat szereztem; amihez csak hozzáértem, megnőtt, mint a lép. $S$ mikor már lassanként nagyobb lett a birtokom, mint egész szülőföldem határa, félretettem a számolótáblát: visszavonultam az üzleteléstől, s kezdtem szabadosaimat foglalkoztatni” (Horváth István Károly fordítása). ${ }^{30} \mathrm{Ez}$ esetben Révay József jobban megértette a szöveg utalásait: „Haladéktalanul magamhoz váltottam gazdám minden birtokát" - vagyis a kereskedelmi vállalkozáshoz szükséges tőkét az örökölt földek elzálogosításával szerezte. A szövegkritikailag problémás comparo venalitia, amelyet Horváth István Károly „fölvásároltam az egész rabszolgapiacot”-nak fordított, tkp. „szereztem rabszolgákat”, vagy csupán „felvásároltam mindenféle eladó portékát”. Végül a coepi (per) libertos faenerare kifejezést ugyancsak Révay adta vissza helyesen: „kezdtem pénzkölcsönöket adni a felszabadított rabszolgáknak." ${ }^{31}$

Nem kérdés, hogy Trimalchio vagyona birtokaiban feküdt. „Magának Trimalchiónak akkora a birtoka, hogy a sólyom sem volna képes berepülni” (Horváth István Károly) (37, 8: ipse [Trimalchio] fundos habet, quantum milvi volant) - mondja a lakoma egyik vendége. Más római szatíraszerzőkből ítélve itt egy közismert szólással élt Petro-

27 „Une... énumeration d'allure proverbiale”, Veyne: i. m. (7. jegyz.) 233. n. 41.

28 D. Musti: Il commercio degli schiavi e del grano: Il caso di Puteoli. Sui rapporti tra economia italiana della tarda Repubblica e le economie ellenistiche. In: The Seaborne Commerce of Ancient Rome: Studies in Archaeology and History. Eds. J. H. D’Arms - E. C. Kopff. Rome 1980. 197-216.

29 Erre egyébként Bodel: i. m. (26. jegyz.) 83 is felfigyelt: „Trimalchio characterized by a disconcerting mixture of vulgarity and elegance, offering modest dining with a veneer of sophistication and refinement."

30 Sat. 76, 8-10: Statim redemi fundos omnes, qui patroni mei fuerant. Aedifico domum, <comparo> venalicia, coemo iumenta; quicquid tangebam, crescebat tamquam favus. Postquam coepi plus habere quam tota patria mea habet, manum de tabula: sustuli me de negotiatione et coepi (per) libertos faenerare.

31 Nicolaus Heinsius 1709-es Petronius-kiadásában a <per> libertos betoldást javasolta, ami úgy módosítaná a szöveg jelentését, hogy Trimalchio „felszabadítottjain keresztül” adott pénzkölcsönöket. A faeneratorokról lásd K. Verboven: Faeneratores, Negotiatores and Financial Intermediation in the Roman World (Late Republic and Early Empire). In: Pistoi dia tén technén. Bankers, Loans and Archives in the Ancient World: Studies in Honor of Raymond Bogaert. Eds. K. Verboven - K. Vandorpe - V. Chankowski. Leuven 2008. 211-229. 
nius. ${ }^{32}$ Maga Trimalchio így írja le birtokait: „Az istenek kegyelme folytán nem vásárolom [ti. a bort]; minden, ami csak szem-szájnak ingere, azon a tanyámon (suburbano = város környéki birtokomon) terem, amelyet még nem is ismerek. Azt mondják, hogy határos Tarraco [helyesen: Tarracina] és Tarentum környéki birtokaimmal. Most éppen Szicíliát szeretném földecskéimmel egybekapcsolni, hogy ha kedvem szottyan Afrikába utazni, saját mezsgyéim mentén hajózhassak" (Horváth István Károly). ${ }^{33}$ Mindez persze csak vicc, és annak illusztrálására szolgál, hogy a bugris parvenü nemcsak a mitológiához nem ért, de a földrajzról sincsenek fogalmai. Az idézett szöveg esetében a Gareth Schmeling által használt „garbled mythology” mintájára akár "garbled geography”-ról is beszélhetnénk. ${ }^{34}$ Valójában még azt sem kell túl komolyan venni, hogy Trimalchio a város környéki birtokain szőlőt termeszt és bort készít, mivel ez esetben is egy szándékoltan zavaros leírással találkozunk: „Minden megterem a saját gazdaságában: gyapjú, citrom, bors, s ha netán kakastejre támad kedved, azt is megtalálod nála” (Horváth István Károly). ${ }^{35} \mathrm{~A}$ fordítás itt sem pontos, és éppen a lényeg sikkad el benne: Trimalchio birtokain csupa egzotikus dolog terem, amelyekről egyébként minden normális ember tudja, hogy Itáliában nem találhatók. P. A. George javításában a lana helyett laina szerepel, amely egy egzotikus fafajta, valamiféle mastix (Plin. NH XII, 72). A citrea („citrom”) viszont Jacobs konjektúrája, amire semmi szükség, hiszen a cedria vagy cédrusolaj, vagy a cédrusfa mézgája (Plin. NH XXIX, 47), ez a fafaj pedig szintén nem őshonos Itáliában. A piper természetesen csak Indiában terem meg, a „kakastej” pedig csupán egy fikciós metafora valamilyen „mesebelien finom” ételről.

Eddig szó esett Trimalchio „város körüli” (suburbanus) földjeiről, amely talán a Puteoli körül fekvő területekre vonatkozik. ${ }^{36}$ A Satyricon azonban megemlít más fundusokat is: „Ha majd Apulia földjeit is birtokomhoz csatolhatom, akkor majd elmondom, hogy eleget éltem” (Horváth István Károly); ${ }^{37}$ „a cumaei birtokon, amely Trimalchio tulajdonát képezi, harminc fiú és negyven leány született; a szérüről a csűrbe behordatott

32 Vö. Juv. Sat. IX. 54-55: dic, passer, cui tot montis, tot praedia servas / Apula, tot milvos intra tua pascua lassas?; Pers. Sat. IV. 25-26: quaesieris nostin Vettidi praedia? cuius? / dives arat Curibus quantum non milvus errat.

${ }_{33}$ Sat. 48, 2-3: Non emo, sed nunc quicquid ad salivam facit, in suburbano nascitur eo, quod ego adhuc non novi. Dicitur confine esse Tarraciniensibus et Tarentinis. Nunc coniungere agellis Siciliam volo, ut cum Africam libuerit ire, per meos fines navigem.

34 G. Schmeling: (Mis)uses of Mythology in Petronius. In: Vertis in usum. Studies in Honor of Edward Courtney. Eds. J. F. Miller - C. Damon - K. S. Myers. München - Leipzig 2002. 152-163.

${ }_{35}$ Sat. 38,1: Omnia domi nascuntur: laina [lana], cedria [citrea], piper; lacte gallinaceum si quaesieris, invenies.

36 Puteoli coloniát Kr. e. 194-ben alapították, de a kb. $500 \mathrm{~km}^{2}$-es ager Campanust már Kr. e. 211-ben a római állam kisajátította. Ez volt Itália egyik legtermékenyebb területe (Liv. XXVI. 26.7). A centuriatiók nyomait sok helyütt megtalálták, lásd M. Pagano: Nuovi cippi anepigrafi della centuriazione romana da Allifae, Capua, Puteoli e Setia. RAAN 59 (1984) 173-188; G. Chouquer-M. Clavel-Lévêque - F. Favory-J.-P. Vallat: Structures agraires en Italie Centro-Méridionale. Cadastres et paysage ruraux. Roma 1987.

37 Sat. 77,3: Quod si contigerit fundos Apuliae iungere, satis vivus pervenero. 
ötszázezer vékányi búza; ötven ökör töretett igába” (Horváth István Károly). ${ }^{38}$ Nyilvánvalóan ezek is mesebeli számadatok, ezért felesleges volna valószerűségüket firtatni. A birtokok (fundi, praedia) földrajzi elhelyezkedése azonban érdekes: Puteoli, Cumae, Apulia, Tarracina, Tarentum és majd talán Szicília. Trimalchio actuariusa, vagyis számvevőrabszolgája megemlíti, hogy tavaly megvették a horti Pompeianit $(53,5)$, amelyet Révay „Pompeius-féle kertek”-nek, Horváth pedig „Pompeius kertjei”-nek fordít, pedig valószínű, hogy itt nem a híres római kertekről, hanem egy Pompeii körüli villáról lehet szó. ${ }^{39}$ (A hortus ugyanis villa suburbana jelentésben is állhat, például Cic. Att. IX, 13: cui Gnaeus noster locum ubi hortos aedificaret dedi.) Összefoglalóan: Trimalchio azzal dicsekszik, hogy „a Rák alatt születtem én: ezért állok sok lábon, és szárazon is, tengeren is rengeteg a birtokom; mert a rák ott is, itt is megél” (Horváth István Károly). ${ }^{40}$ Talán szerencsésebb az in mari et in terra multa possideo Révay-féle fordítása („ezért van anynyim tengeren és szárazföldön"), mivel a tengeren aligha lehetnek bárkinek is birtokai. Viszont jogosan vetődik fel a kérdés: mi lehetett az a „sok minden”, amit Trimalchio a tengeren birtokol? Minden bizonnyal hajók, vagyis ezek szerint a tengeri kereskedelemmel sem hagyott fel? Vagy a felszabadítottaknak való pénzkölcsönzés esetleg „tengeri kölcsönöket" jelentett? ${ }^{41}$

Az alábbiakban Trimalchio síremlékét és sírfeliratát fogjuk közelebbről megvizsgálni. A fennmaradt római feliratoknak legalább kétharmada sírfelirat, vagyis az egyéni emlékezet megőrzésére hivatott emlék. Ezek azonban - mint azt Alföldy Géza is megállapította - a legritkább esetben elégítik csak ki az életrajz követelményét. ${ }^{42} \mathrm{~A}$ római biográfiának megvoltak a maga kanonikus témái: a név, származás, társadalmi pozíció mellett a magánélet, a szellemi és fizikai tulajdonságok, a neveltetés, az emlékezetre méltó tettek, a halál körülményei és az utókor megítélése szerepelt ezek között. „A fel-

38 Sat. 53,2: In praedio Cumano quod est Trimalchionis nati sunt pueri XXX, puellae XL; sublata in horreum ex area tritici millia modium quingenta; boves domiti quingenti.

39 S. Wood: Horti in the City of Rome: Emulation and Transcendence in the Late Republic and Early Empire. In: TRAC 2009: Proceedings of the Nineteenth Annual Theoretical Roman Archaeology Conference, Michigan and Southampton 2009. Eds. G. Taylor - E. Harris - P. Girdwood - L. Shipley. Oxford 2010. 75-90.

40 Sat. 39, 8: In cancro ego natus sum. Ideo multis pedibus sto, et in mari et in terra multa possideo; nam cancer et hoc et illoc quadrat.

41 G. E. M. de Ste Croix: Ancient Greek and Roman Maritime Loans. In: Debits, Credits, Finances and Profits. Essays in Honour of W. T. Baxter. Eds. H. Edey - B. S. Yamey. London 1974. 41-59; J. Rougé: Prêt et société maritimes dans le monde romain / Maritime Loans and Maritime Associations in the Roman World. MAAR 36 (1980) 291-303; P. Millett: Maritime Loans and the Structure of Credit. In: Trade in the Ancient Economy. Eds. P. Garnsey - K. Hopkins. Berkeley - Los Angeles 1983. 36-52.

42 Alföldy G.: Életrajzok és feliratok a római világban. ÓkÉ 11 (2003) 3-13; G. Alföldy: Inschriften und Biographie in der römischen Welt. In: Biographie und Prosopographie. Internationales Kolloquium zum 65. Geburtstag von Anthony R. Birley 28. September 2002, Schloss Mickeln, Düsseldorf. Hrsg. K. Vössing. Stuttgart 2005. 29-52. Vö. W. Eck: 'Tituli honorarii', curriculum vitae und Selbstdarstellung in der Hohen Kaiserzeit. In: Acta Colloquii epigraphici Latini: Helsingiae 3-6. Sept. 1991 habiti. Eds. H. Solin - H. O. Salomies - U. Lierz. Helsinki 1995. 211-237; Inschriftliche Denkmäler als Medien der Selbstdarstellung in der römischen Welt. Hrsgg. G. Alföldy - S. Panciera. Stuttgart 2001. 
iratok még csak »rövidített biográfiaként « (Kurzbiographie) sem jellemezhetők. Céljuk nem az volt, hogy az egyes személyek életrajzát nyújtsák, hanem az, hogy létüket és a társadalomban elfoglalt helyüket dokumentálják." ${ }^{43} \mathrm{~A}$ „perszonalizált feliratkultúra” ${ }^{{ }^{44}}$ fó hordozói olyan személyek voltak, akik alacsony rangból emelkedtek a kiváltságos ordines közé (felszabadított rabszolgák, municipiális arisztokrácia, katonák). Az ilyen sikeres társadalmi felemelkedők voltak azok, akik gyakran hivatkozhattak életútjuk során valamilyen nevezetes eseményre, tettre, s ők voltak, akik új exemplumokkal gyarapították a tradicionális társadalmi és erkölcsi értékrendszert. Alföldy szerint Trimalchio sírfelirata nem más, mint ezeknek a feliratoknak a karikatúrája. Az igazi római arisztokraták - mint Plinius két kiemelkedő senatorkortársa - nem foglalkoztak sokat tetteik kőbe vésésével. Verginius Rufus a következő feliratot vésette síremlékére: Hic situs est Rufus, pulso qui Vindice quondam / imperium adseruit non sibi sed patriae (Plin. Epist. VI, 10, 3-5); Sextus Iulius Frontinus pedig e szavakkal tiltotta meg, hogy számára síremléket létesítsenek: Impensa monumenti supervacua est, memoria nostri durabit, si vita meruimus (Plin. Epist. IX, 19, 1-8).

Ezek után lássuk Trimalchio síremlékének leírását, amit Horváth István Károly (HIK) és Révay József (RJ) fordításainak ${ }^{45}$ kritikája követ, majd megkísérlem a szöveget saját fordításomban visszaadni.

(5) Respiciens deinde Habinnam: Quid dicis, inquit, amice carissime? Aedificas monumentum meum quemadmodum te iussi? (6) Valde te rogo, ut secundum pedes statuae meae catellam fingas ${ }^{46}$ et coronas et unguenta et Petraitis omnes pugnas, ut mihi contingat tuo beneficio post mortem vivere; praeterea ut sint in fronte pedes centum, in agrum pedes ducenti. (7) Omne genus enim poma volo sint circa cineres meos, et vinearum largiter. Valde enim falsum est vivo quidem domos cultas esse, non curari eas, ubi diutius nobis habitandum est. Et ideo ante omnia adici volo: HOC MONUMENTUM HEREDEM NON SEQUITUR. ${ }^{47}$ (8) Ceterum erit mihi curae, ut testamento caveam ne mortuus iniuriam accipiam. Praeponam enim unum ex libertis sepulchro meo custodiae causa, ne in monumentum meum populus cacatum currat. (9) Te rogo, ut naves etiam <in fronte $>$ [monumenti mei] ${ }^{48}$ facias plenis velis euntes, et me in tribunali sedentem praetextatum cum anulis aureis quinque et nummos in publico de sacculo effundentem; scis enim, quod epulum

43 Alföldy: i. m. (42. jegyz.) 1.

44 Alföldy: i. m. (42. jegyz.) 12.

45 Petronius: Satyricon (Bibliotheca Classica), ford. Horváth István Károly. Budapest 1972. - Petronii Cena Trimalchionis / Petronius: Trimalchio lakomája, ford. Révay József. Budapest 1977.

46 fingas Scheffer, ponas Bücheler, pingas Codex Parisiensis Lat. 7989 (H). Az alapszöveg kiválasztásában és az apparatus criticus idézésénél az alábbi munkát követtem: Petronii Arbitri Cena Trimalchionis. Ed. M. S. Smith. Oxford 1975. 42-43.

47 sequatur $H$, sequitur Bücheler. A feliratokon a sequitur és a sequetur alak is előfordul, lásd később.

48 monumenti mei delevit Müller, <in fronte> monumenti mei Keller, RhM 16 (1861) 549, <in lateribus> monumenti mei Bücheler. 
dedi binos denarios. Faciatur, si tibi videtur, et triclinia. (10) Facies et totum populum sibi suaviter facientem. ${ }^{49}$ (11) Ad dexteram meam pones ${ }^{50}$ statuam Fortunatae meae columbam tenentem, et catellam cingulo alligatam ducat, et cicaronem meum, et amphoras copiose ${ }^{51}$ gypsatas, ne effluant vinum. Et unam ${ }^{52}$ licet fractam sculpas, et super eam puerum plorantem. Horologium in medio, ut quisquis horas inspiciet, velit nolit, nomen meum legat. (12) Inscriptio quoque vide diligenter si haec satis idonea tibi videtur: C. POMPEIVS TRIMALCHIO MAECENATIANVS HIC REQVIESCIT HVIC SEVIRATVS ABSENTI DECRETVS EST CVM POSSET IN OMNIBVS DECVRIIS ROMAE ESSE TAMEN NOLVIT PIVS FORTIS FIDELIS EX PARVO CREVIT SESTERTIVM RELIQVIT TRECENTIES NEC VNQVAM PHILOSOPHVM AVDIVIT VALE ET TV.

(71, 5-12, ed. Smith)

(5) amice carissime: „édes barátom” (RJ), „legdrágább barátom” (HIK), az előbbi a köznyelvibb, ezért jobb megoldás. (6) pingas: „mintázz” (HIK), „faragj” (RJ), a pingo szó alapjelentése „festeni”, de az „ábrázolni” általános értelemben is használják, a szobortalapzatokra nyilván az utóbbi jelentés illik jobban; in fronte pedes centum, in agrum pedes ducenti: „hosszában száz, szélességében kétszáz láb legyen” (RJ), „homlokzata százlábnyi széles $s$ az egész legalább kétszáz láb hosszúságú legyen" (HIK), a „homlokzat” megoldás jó, de nincs benne az in agro, és kissé körülményesen van fordítva, természetesen az in fronte... in agrum pedes egy rögzült formula a sírfeliratokon, vö. mille pedes in fronte, trecentos cippus in agros (Hor. Sat. I, 8, 12-13)..$^{53}$ (7) omne genus enim poma volo sint circa cineres meos, et vinearum largiter: "azt akarom, hogy mindenféle gyümölcsfa legyen a hamvaim körül és nagy-nagy szőlőskert” (RJ), a largiter jelentése „bőven”, nemcsak a szőlőskert kiterjedésére, hanem a remélt termés nagyságára is vonatkozhat; „azt akarom, hogy hamvaim körül, szerteszét, mindenfajta gyümölcsfák és szőlőtőkék viruljanak" (HIK), az utóbbi túl van fordítva, ráadásul a síremlékek körül tényleg lehettek szőlőskertek, nem csupán szőlőtőkék (lásd alább); valde enim falsum est vivo quidem domos cultas esse, non curari eas, ubi diutius nobis habitandum est: „nagyon elhibázott dolog, ha életünkben pazar lakásunk van, nem törődni azzal, ahol hosszabb ideig lakunk” (RJ), a „pazar lakás” nem jó fordítás, egyrészt mert a domus házat jelent, a cultus jelentése pedig "gondozott, ápolt, megművelt", a curarival állítható párhuzamba; „mert helytelen dolog volna, ha olyan emberek, akik életükben müvelt környezetben éltek, nem törődnének azzal a lakásukkal, amelyben sokkal tovább kell tartózkodniuk” (HIK), a „müvelt környezet” nem annyira köznyelvi, s az egész mon-

49 faciantur Goesius, faciatur $H$, facias Bücheler.

50 ponas vulgo, pones $H$.

51 copiose George, copiosas $H$.

52 unam $H$, urnam Iacobus Gronovius et Bücheler.

53 T. Mommsen: Zum römischen Grabrecht. ZSSR Romanistische Abteilung 16 (1895) 203-220; $N$. Brundrett: Roman Tomb Gardens: The Construction of Sacred Commemorative Landscapes. Brock Review 11 (2011) 51-69. 
dat túl körülményes. (8) ne mortuus iniuriam accipiam: „haló poromban csúfság ne érjen” (RJ), nagyon igényes a mortuus megoldása, de az iniuria kifejezetten jogsértést jelent; ${ }^{54}$ „halálom után semmilyen gyalázat ne érhessen” (HIK), a kérdés itt is az, hogy a mondatot az előző HMHNS-hez kötjük, vagy a következőben elhangzó cacatumhoz, a „gyalázat” is inkább a csúfsághoz áll közel, vagyis mindkét fordító inkább a következő mondathoz igazítja a jelentést; ne in monumentum meum populus cacatum currat: „nehogy az emberek a síremlékem mellé járjanak odarondítani” (RJ), eufemisztikus megoldás; „nehogy a nép a síremlékemre járjon szarni” (HIK), szó szerinti megoldás, talán csak a curratot nem sikerült egyiknek sem visszaadni, tehát ha „sürgős dolguk akad” vagy „szaladniuk kell”.55 (9) naves etiam <in fronte> monumenti mei facias plenis velis euntes: „faragj ki a síremlékem felső részén dagadó vitorlákkal sikló hajókat” (RJ), a „felső részén” nincs benne, az in fronte is coniectura, és azt jelenti: „homlokzatán”; „sírkövemre faragj duzzadó vitorlákkal tovaszáguldó hajókat” (HIK) kihagyja a betoldást, az euntesnek talán a „sikló” jobban megfelel, mint a kissé túlfordított „tovaszáguldó"; me in tribunali sedentem praetextatum cum anulis aureis quinque et nummos in publico de sacculo effundentem: „engem, amint bíborszegélyes togában, öt aranygyűrűvel ujjaimon az emelvényen ülök, és erszényemből pénzt szórok a nép közé” (RJ), „engem is, amint öt aranygyürüvel, bíbortogában, a bírói széken ülök, és zsákszámra szórom a pénzt a nép közé" (HIK), mindegyikben van jó és rossz megoldás: a tribunal jelentése valójában „bírói emelvény”, a praetextatum természetesen „bíborszegélyes toga” és nem „bíbortoga”, a sacculum viszont „zsákocska” (és nem erszény, ami sokkal kisebb), de csak egy, amiből az következik, hogy a „zsákszámra” is túlfordítás; scis enim, quod epulum dedi binos denarios: „hiszen tudod, hogy megvendégeltem a népet, s két-két dénárt adtam mindenkinek” (RJ), „hiszen tudod, hogy népünnepélyt rendeztem, és két-két denariust adtam mindenkinek" (HIK), az epulum ünnepi lakomát jelent, amelynek keretében történt a pénzosztás; faciatur, si tibi videtur, et triclinia: „ha jónak látod, lakomát is kifaraghatsz rajta” (RJ), teljesen félreértette a dolgot; „faragtassék a sírkőre, ha te is úgy gondolod, egy ebédlőterem is" (HIK), ez is félreértés, hiszen a triclinium (singularisban) valóban jelenthet „ebédlőtermet”, de itt pluralis szerepel; a faciatur... triclinia szemantikailag még az előző mondathoz tartozik, azt értelmezi, mi-

54 Ugyanígy értelmezi Paul Veyne is, aki a Digesta XXXII. 94 alapján felhívja a figyelmet arra a jogsértésre, hogy a neveket kivéshették a feliratokról, lásd $S$. Ratti: Le monde du Satyricon et la maison de Pline le Jeune. Anabases: Traditions et Réceptions de l'Antiquité 13 (2011) 79-94.

55 A cacator cave malum pompeii graffitókon gyakran feltűnő fenyegetés (e.g. CIL IV 3782, 4586, 5438, 6641 etc.), egy jól ismert hosszabb sírfeliraton is szerepel: Hospes adhuc tumuli $n<e=I>$ meias ossa prec[antur] / nam si vis (h) uic gratior esse caca / Urticae monumenta vides discede cacator / non est hic tutum culu(m) aperire tibi (CIL IV 8899), cf. W. D. Lebek: Romana simplicitas in lateinischen Distichen aus Pompei. ZPE 22 (1976) 287-292; L. Koenen: Urticae monumenta. ZPE 31 (1978) 85-86; S. Levin-Richardson: Bodily Waste and Boundaries in Pompeian Graffiti. In: Ancient Obscenities. Their Nature and Use in the Ancient Greek and Roman Worlds. Eds. D. Dutsch - A. Suter. Ann Arbor 2015. 225-254; A. Varone: Newly Discovered and Corrected Reading of "iscrizioni privatissime" from the Vesuvian Region. In: Inscriptions in the Private Sphere in the Greco-Roman World. Eds. R. Benefiel - R. Keegan. Leiden 2016. 113-130. 
vel az epulumhoz szokás volt heverőket is készíttetni, ahogyan erről több feliraton is olvashatunk. ${ }^{56}$ (10) facies et totum populum sibi suaviter facientem: „kifaraghatod azt is, amint az egész nép kedvére mulatozik” (RJ), jelentősen alulfordította; „ezt esetleg úgy is megcsinálhatnád, hogy benne az egész nép jól érzi magát” (HIK), a „benne” névmással visszautal az előző mondatban (rosszul) szereplő „ebédlőterem”-re; a sibi suaviter facere általában olyasmit jelent, hogy valaki ,jól érzi magát”, de egy Cataniában talált graffito alapján bizonyos, hogy sikamlós értelemben is használták (AE 1919, 57), csakúgy mint egy Puteoliban talált falfestményen, ahol éppen egy lakoma résztvevői „érzik jól magukat” félreérthetetlen helyzetben. ${ }^{57}(11)$ catellam cingulo alligatam ducat: „vezessen kis kutyát övéhez kötözve” (RJ), hibás fordítás; „kutyáját pórázon vezeti” (HIK), ez a helyes megoldás, de a catella kicsinyitő képzős, becéző alakja elsikkad; cicaronem meum: „az én kedvencemet” (RJ), ,az én kis szépfiúmat” (HIK), egyértelműen az utóbbi a helyes, hiszen az egyébként ismeretlen eredetű cicaro és a hasonló jelentésű delicia(e) másutt is feltünik a regényben $(28,4 ; 46,3 ; 64,5 ; 75,11) ;{ }^{58}$ amphoras copiosas gypsatas, ne effluant vinum: ,jó nagy amforákat, lepecsételve, hogy ki ne folyjon belőlük a bor” (RJ), ,jó öblös korsókat, de legipszelve, hogy ki ne folyjék belölük a bor” (HIK), az amfora jobb megoldás, mint a korsó (hiszen egy amforába 26-28 liter folyadék fért, míg egy korsóba legfeljebb 3-4 liter), ugyanakkor a „lepecsételt” mást jelent, mint a „legipszelve", hisz az utóbbi légmentes záródást biztosított, így ez a jobb megoldás (vö. 34, 6: amphorae gypsatae); et $\mathbf{u}[\mathbf{r}] \mathbf{n a m}$ licet fractam sculpas, et super eam puerum plorantem: „összetört hamvvedret is kifaraghatsz és egy fiút, amint ráborulva zokog” (RJ), „kifaraghatsz egy széttört urnát is, és egy fiút, amint az urnára borulva zokog” (HIK), szövegkritikailag problémás hely, mindkét fordító a kéziratokban szereplő unam helyett Bücheler javítását, az urnamot fogadta el, pedig az előbbinek is lenne értelme: unam (sc. amphoram) licet fractam, ez esetben az egyik amforát kellett volna törötten kifaragni, és a puer (rabszolgafiú) azért sírt volna felette, mert félt, hogy a veszteség miatt gazdája megbünteti (lásd alább). (12) Maecenatianus: „Maecenatianus” (RJ), egyszerüen második cognomenként vagy adnomenként értelmezi, és nem fordítja le; „a nagy Maecenas” (HIK), abban az értelemben nem rossz megoldás, hogy felvett névről van szó: „mintha egy alacsony származású, de sikeres amerikai üzletember a Rockefeller nevet venné fel

56 epulum in XIIII [tricli]n(iis) XXXIIII [biclin(iis)], Arles, CIL XII 697 = AE 1965, 270. Friedländer egy ostiai feliratot idézett, amelyen P. Lucilius Gamala epulum trichlinis CCXVII colonis dedit (CIL XIV 375), lásd M. Cébeillac: Lévergétisme des magistrats du Latium et de la Campanie des Gracques à Auguste à travers les témoignages épigraphiques. MEFRA 102 (1990) 699-722; H. D. John: P. Lucilius Gamala's Feasts for the Ostians and Their Roman Models. JRA 13 (2000) 192-200.

57 CIL IV 3442 facitis vobis suaviter ego canto, cf. P. Howell: Some Elucidations of Petronius' Cena Trimalchionis. ICS 9 (1984) 35-41, különösen 39.

58 A. J. Pomeroy: Trimalchio as 'Deliciae'. Phoenix 46 (1992) 45-53; C. Laes: Desperately Different? Delicia Children in the Roman Household. In: Early Christian Families in Context. An Interdisciplinary Dialogue. Eds. D. L. Balch - C. Osiek. Grand Rapids - Cambridge (Mass.) 2003. 298-324. 
magára”; 59 huic seviratus absenti decretus est: „távollétében tisztelték meg az elöljárói méltósággal” (RJ), nem értette a seviratus jelentőségét; „a hattagú hivataltestület tagságát távollétében kapta meg” (HIK), a seviratus „hattagú hivataltestület”-ként kissé túl van fordítva; tamen noluit: „de nem tette” (RJ), „nem tartott rá igényt” (HIK), vagy még egyszerűbben csak „nem akarta”; pius fortis fidelis: „jólelkű, erős, igaz ember volt” (RJ), „kötelességtudó, megbízható, bátor ember volt” (HIK), egyik sem találja el a megfelelő szavakat a megfelelő sorrendben; ex parvo crevit: „kevésből sokra vitte” (RJ), „senkiből lett valakivé" (HIK), mindkettő érdekes megoldás, egyébként Trimalchio egyik szófordulata: de nihilo crevit (38), ab asse crevit (43), cf. Q. Minucius Faber ab asse quaesitum (CIL V 7647), ab asse posit (CIL V 6623); sestertium reliquit trecenties: a 30 millió a nápolyi származású Stertinii család legendás vagyona volt; ${ }^{60}$ nec unquam philosophum audivit: „pedig filozófust sohasem hallgatott” (RJ), „bár tudománnyal sohasem foglalkozott” (HIK), a szó szerinti fordítás itt elegendő; vale et tu: „vándor! minden jót néked is” (RJ), egyértelműen túl van fordítva, a viator vale-típusú feliratzáró formulák hatására, csakhogy a „vándor” a szövegben nem szerepel; „isten veled - veled is” (HIK), jobb megoldás, csak az istent kár belekeverni.

Azután Habinnashoz fordult: Mit szólsz, édes barátom? Megépíted-e a síremlékemet, ahogyan megrendeltem nálad? (6) Nagyon szépen kérlek, tégy a szobrom talapzatára kiskutyát, koszorúkat, kenőcsös edényeket és Petraites valamennyi viadalát, hogy jóvoltodból a halálom után is tovább éljek; továbbá az utcafronti része 100 láb és a mező felé 200 láb legyen. (7) Mert azt akarom, hogy hamvaim körül mindenféle gyümölcs legyen, és szőlők is bőven. Mert nagyon elhibázott dolog, ha az ember addig, amíg él, törődik a házaival, de nem gondoskodik azokról, amikben hosszabb ideig kell laknunk. Ezért mindenekelőtt ez álljon rajta: EZ A SÍREMLÉK NEM LEHET ÖRÖKÖSÉ. (8) Egyébként gondom lesz rá, hogy végrendeletemben vigyázzak arra: haló poromban ne érjen jogtalanság. Szabadosaim egyikét odaállítom sírom őrzésére, nehogy a nép az emlékművemhez szaladjon kakálni. (9) Arra kérlek, készíts a síremlékem elülső részére dagadó vitorlákkal járó hajókat, és tégy rá engem, amint bíborszegélyes togában, öt aranygyürüvel az ujjaimon ülök egy emelvényen, és egy zsákból pénzt szórok nyilvánosan, hisz tudod, hogy fejenként két denariust érő lakomát adtam! Ha jónak látod, a lakomához használt heverők is rajta lehetnek. (11) Ráteheted az egész népet is, amint épp tivornyáznak. (11) Jobbom felöl helyezd el Fortunatám szobrát, amint galambot tart a kezében, vezessen egy pórázra kötött kutyust, és az én kedvencemet is, meg jó nagy begipszelt amforákat, hogy ki ne folyjon a bor. És egyet összetörve is oda faraghatsz, amelyre rá-

59 T. Ramsby: Reading the Freed Slave in the Cena Trimalchionis. In: Free at Last! The Impact of Freed Slaves on the Roman Empire. Eds. S. Bell - T. Ramsby. London - New York 2012. 66-87, különösen 81; cf. B. Baldwin: Trimalchio and Maecenas. Latomus 43 (1984) 402-403.

60 E. Kind: Stertinius Xenophon. PWRE III A 2 (1929) col. 2450-2451; R. Wolters: C. Stertinius Xenophon von Kos und die Grabinschrift des Trimalchio. Hermes 127 (1999) 47-60. 
borulva egy fiú zokog. Középre tegyél egy napórát, hogy akárki nézi meg, hány óra van, akarja vagy sem: elolvassa a nevemet. (12) Azt is alaposan vizsgáld meg, hogy elég jónak tủnik-e számodra ez a sírfelirat: C. POMPEIUS TRIMALCHIO MAECENATIANUS NYUGSZIK ITT, AKIT TÁVOLLÉTÉBEN VÁLASZTOTTAK A HATOS TESTÜLET TAGJÁVÁ. HELYET FOGLALHATOTT VOLNA RÓMA BÁRMELYIK DECURIÁJÁBAN, DE NEM AKARTA. KEGYES, ERŐS ÉS HÜSÉGES. KEVÉSBŐL SOKRA VITTE, HARMINCMILLIÓ SESTERTIUST HAGYOTT HÁTRA, PEDIG FILOZÓFUST SOSEM HALLGATOTT. MINDEN JÓT - NEKED IS.

\section{Trimalchio síremléke}

Az egyfolytában halálára készülő Trimalchio gondolatvilágának középpontjában majdani síremléke áll (71, 5-12). Ez persze önmagában nem probléma, hiszen még az ifjabb Plinius is azt vallotta: „olyan egykettőre elfelejtjük a megholtakat, hogy legjobb, ha mi magunk építjük meg síremlékünket, s mi magunk rendezünk el előre mindent az örökösök helyett” (Epist. VI, 10, 5-6. Muraközy Gyula fordítása). A cena házigazdája minden bizonnyal a lakoma többi vendégével együtt - meg van győződve róla, hogy a monumentum révén „osztályrészéül juthat a halál utáni élet” (mihi contingat... post mortem vivere). Nyilván abban a nézetben is sokan osztoztak, hogy a síremléknek az elhunyt múltjára vonatkozó emlékeket és nem az ismeretlen túlvilágra vonatkozó elképzeléseit kell tükröznie. Ekként Trimalchio sírja is Trimalchio jellemét és tetteit szimbolizálja. A síremlék puszta méretei is mutatják: az abban nyugvó halott élete egy sikertörténet volt, ami a többiek számára is példaként szolgálhat. Rabszolgából úr lett, kevésből sokra vitte, és sosem adta fel. „Vedd kezedbe hát te is a sorsodat”, „segíts magadon, s az isten is megsegít" - valami efféle közhely-filozófia lehetett az az üzenet, amelyet Trimalchio halála után is közvetíteni akart, s amelyet környezete bizonyára meg is értett, mint ahogyan ma is megért.

Petronius hősének, Trimalchiónak síremléke és sírfelirata Theodor Mommsen 1878-ban megjelent tanulmánya óta szünet nélkül a filológusok, epigráfusok és társadalomtörténészek érdeklődésének homlokterében áll. ${ }^{61}$ A képzelet szülte síremléket összehasonlították már olyan valóságban is létező monumentumokkal, mint Eurysaces péknek a Porta Maggiore mellett álló síremléke (Kr. e. 50-20 között), vagy az ún.

61 T. Mommsen: Trimalchios Heimath und Grabschrift. Hermes 13 (1878) 106-121; E. Hübner: Zum Denkmal des Trimalchio. Hermes 13 (1878) 414-422; L. Pepe: Sul monumento sepolcrale di Trimalchione. GIF 10 (1957) 293-300; P. Tremoli: Le iscrizioni di Trimalchione. Trieste 1960; J. F. Donahue: Euergetic SelfRepresentation and the Inscription at Satyricon 71.10. CPh 94 (1999) 69-74; J. Daheim - J. Blänsdorf: Petron und die Inschriften. In: Petroniana. Gedenkschrift für Hubert Petersmann. Hrsgg. J. Herman - H. Rosén. Heidelberg 2003. 95-107; V. M. Hope: At Home with the Dead. Roman Funeral Traditions and Trimalchio's Tomb. In: Petronius. A Handbook. Eds. J. Prag - I. Repath. Malden - Oxford 2009. 140-160; U. Roth: An (Other) Epitaph for Trimalchio: Sat. 30.2. CQ 64 (2014) 422-425. 
Igeler Säule, melyet a textilkereskedő Secundinius-testvérek emeltek Kr. u. 250 körül. ${ }^{62}$ Azonban csakúgy, mint Trimalchio „gazdasági hátterének” vizsgálatakor, itt is ügyelnünk kell arra, hogy miközben a regény hátterében álló valóságra akarunk rámutatni, ne tévesszük szem elől, hogy valójában mindvégig irodalmi fikcióval van dolgunk. Annál is inkább, mivel az irodalomtudomány kimutatta, hogy a görög-római regényekben, például az ephesosi Xenophón, Charitón, Antónios Diogenés, valamint az ismeretlen szerzőségü Apollónios tyrusi király története címü alkotásban az auctorok olyan helyzetekben alkalmazzák a fiktív feliratokat (a főhősöknek vagy a főhősök által állított dedikációk, sírfeliratok formájában), ahol a regény valószerüsítése ezt irodalmilag megkívánja (Beglaubigungsapparat). ${ }^{63}$

„A sír olyan ház, ahol az ember hosszabb ideig lakik, mint a földi házában” - osztja meg bölcsességét Trimalchio a lakomavendégeivel. Közismert, hogy a sír mint „örök

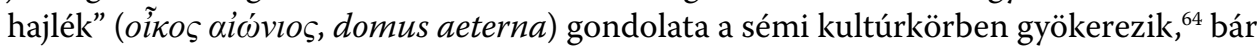
ha szó szerint vesszük, Trimalchio nem beszél az örökkévalóságról, csupán a földinél hosszabb időről (diutius nobis habitandum est). Erre a gondolatra szinte rárímel az orvos C. Hostius Pamphilus, Caius szabadosa, valamint felesége, Nelpia Hymnis, Marcus szabadosnője sírfelirata: C(aius) Hostius C(aii) l(ibertus) Pamphilus | medicus hoc monumentum | emit sibi et Nelpiae M(arci) l(iberta) Hymnini | et líberteis et líbertabus omnibus | postereisque eorum. | Haec est domus aeterna, hic est | fundus, heis sunt horti, hoc | est monumentum nostrum. | In fronte p(edes) XIII, in agrum p(edes) XXIIII (Róma, Kr. e. I. század, CIL I ${ }^{2} 1325$ VI 6049; ILLRP 932; CLE 1851). ${ }^{65}$ Ez a valós felirat nem csupán azért érdekes számunkra, mert számos ponton nyújt összehasonlítási alapot Trimalchio fiktív epitáfiumával, hanem azért is, mert rámutat az ilyen típusú síremlékek három alapvető összetevőjére: a telekre (fundus), a kertre (hortus) és magára az emlékmüre (monumentum).

Ami Trimalchio síremlékének fundusát illeti: annak mérete (in fronte pedes 100, in agrum pedes 200) kb. 29, 6 m x 59, 2 m (1752,3 m²), elég tekintélyes méretűnek számít.

62 L. H. Petersen: The Baker, His Tomb, His Wife, and Her Breadbasket: The Monument of Eurysaces in Rome. Art Bulletin 85 (2003) 230-257; A. Wilson - K. Schörle: A Baker's Funerary Relief from Rome. Papers of the British School at Rome 77 (2009) 101-123. A. Mehl: Wirtschaft, Gesellschaft, Totenglauben: die Igeler Säule bei Trier und ihre Grabherren. Mit einem Anhang: das Grab des Trimalchio. Laverna 8 (1997) 59-92.

63 M. Mayer y Olivé - M. Miró - J. Velaza: Litterae in titulis, tituli in litteris. Elements per a l'estudi de la interacció entre Epigrafia i Literatura en el món romà. Barcelona 1998; E. Sironen: The Role of Inscriptions in Greco-Roman Novels. In: The Ancient Novel and Beyond. Eds. S. Panayotakis - M. Zimmerman - W. Keulen. Leiden 2003. 289-300; Inscriptions and Their Uses in Greek and Latin Literature. Eds. P. Liddel - P. Low. Oxford 2013. (Az utóbbi kötet több tanulmánya is foglalkozik az Augustus korától a római irodalomban még a szerelmi elégiában is - kimutatható furor epigraphicusszal.)

64 I. Kajanto: On the Idea of Eternity in Latin Epitaphs. Arctos 8 (1974) 59-69; A. Wallace-Hadrill: Housing the Dead: the Tomb as House in Roman Italy. Commemorating the Dead: Texts and Artifacts in Context. New York 2008. 39-77.

65 A felirat elemzését lásd P. Keegan: Reading Epigraphic Culture, Writing Funerary Space in the Roman City. In: Written Space in the Latin West, 200 BC to AD 300. Eds. G. Sears - P. Keegan - R. Laurence. London - New York 2013. 49-64, különösen 57-60. 
John Bodel kimutatásában hasonló méretűekre példa - ugyancsak libertinusoktól - Ti. Claudius Celadus 1259 m²$^{2}$-es sírkertje Velitrae-ből (AE 1925, 92), vagy Aquilia Cariceni coniunx $2057 \mathrm{~m}^{2}$-es hortulus sive pomariumja Lanuviumból (CIL XIV 2139), de nem ritka az 5000, 7000, 10 000, sőt a $20000 \mathrm{~m}^{2}$ feletti sírkert (hortus, ager) sem, a Parmában elhunyt lovagrendi C. Praeconius Ventilius Magnus hortulusa pedig $88130 \mathrm{~m}^{2}$-en terült el (AE 1993, 713). Önmagában Trimalchio kívánsága („mert azt akarom, hogy hamvaim körül mindenféle gyümölcs legyen és szőlők is bőven”) is tipikus példája a korszak temetkezési kultúrájának. ${ }^{66}$ A nagyobb sírterületeken még üzleti célú épületekkel is találkozunk (tabernae, piscinae, horrea). A Ti. Claudius Eutychus császári felszabadított és felesége, Claudia Peloris fundusán épült sír (monumentum) és különböző kiegészítő épületek (aedificia) alaprajzát is megörökítették (formas aedificii custodiae et monumenti reliquerunt, CIL VI 9015, 29847 = ILS 8120). A feliratból is kiderül, hogy az alkalmasint többemeletes épületben nemcsak halotti lakomákat rendeztek, hanem az a kertész(ek) és az őr(ök) lakóhelyéül is szolgált. Erre már valóban illene Statius eksztatikus felkiáltása: „Ház ez, ház csakugyan! Szomorú sírnak ki nevezné?” (Silv. V, 1, 237-238: Domus ista, domus! quis triste sepulcrum / dixerit. Muraközy Gyula fordítása).

Tehát a hortus sepulchralis vagy cepotaphium sem számított ritka jelenségnek. Az Alexandriából származó szokás természetesen legelőször a Campaniai-öböl mentén fekvő városokban jelentkezett Itália földjén. A szentimentális hajlamú költők - és modern irodalomtörténészek - képzeletében a sírkertek olyan locus amoenusok voltak, amelyek az Elysium képzetét idézték fel az arra járókban. És bizonyára voltak ilyenek is, hiszen a rózsa, a méheket hívogató kakukkfü, a szőlő és a déloszi mirtusz mind-mind a sírköltészet részévé váltak, sőt még a Trimalchio által emlegetett gyümölcsök (poma) is beleférnek a felsorolásba. ${ }^{67}$ Csakhogy a rómaiak gondolatvilágában az amoenitas, sőt a sacralitas nagyon is összefért a növények termesztéséből, halak tenyésztéséből vagy a mézkészítésből származó reális haszonnal, különösen ott, ahol ehhez elegendő nagyságú fundus állt rendelkezésre. ${ }^{68}$

66 W. F. Jashemski: Tomb Gardens at Pompeii. CJ 66 (1970-1971) 97-115; V. L. Campbell: Stopping to Smell the Roses: Garden Tombs in Roman Italy. Arctos 42 (2008) 31-43; N. Brundrett: Roman Tomb Gardens: The Construction of Sacred Commemorative Landscapes. The Brock Review 11 (2011) 51-69; J. Bodel: Roman Tomb Gardens. In: Gardens of the Roman Empire. Eds. W. Jashemski - K. Gleason - K. Hartswick A. Malek. Cambridge 2017. 199-242.

67 Például: vitium pomorumque et florum viridumque omnium generum seminibus ea loca... adornaverunt (CIL VI 10237 = ILS 7870); mausoleum excoluit et ut esset fru[giferum feci]t positis arboribus vitibus rosariis (CIL XII 3637); inter pampinea virgulta et gramina laeta umbra super rami virides ubi densa ministrat (AE 1957, 334, Romula); mihi carpe rosas, mihi lilia pone [ca]ndeda\{s\} q(uae) viridis dabit (h)ortulus (AE 1984, 722, Savaria).

68 A kertek (gyümölcsösök, szőlők és halasmedencék) által termelt hasznot hangsúlyozza: N. Purcell: Tomb and Suburb. In: Römischer Gräberstrassen. Hrsgg. H. von Hesberg - P. Zanker. München 1987. 24-41, különösen 35; N. Purcell: The Roman Garden as a Domestic Building. In: Roman Domestic Buildings. Ed. I. Barton. Exeter 1996. 121-152, különösen 123-124. Egy Sucidavából (Dacia) elökerült feliraton külön is rendelkeznek a fructus vinearumról (Kr. u. 150-270, CIL III 14493 = IDR II 187). 
Térjünk rá ezek után Trimalchio és felesége, Fortunata síremlékére. A felszabadítottak körében a Kr. e. I. század első felében jött divatba a síremlékek állítása, melyek közül ma mintegy háromszáz darab ismert. Bár a monumentum alakjára nem utal Petronius, elképzelhető, hogy az ház formájú lehetett. John Bodel szellemes megjegyzése szerint „Trimalchio sírja olyan, mint egy ház, a háza pedig olyan, mint egy sír”. ${ }^{9}$ Az olvasó valahogyan mégis egy grandiózus méretű és alaposan kidolgozott sírt képzel el magának, bár azt sem tudja, hogy kerek vagy négyszögletes alaprajzú lehetett, torony- vagy kamrasírról lehetett-e szó. Végső soron igaza van Valerie Hope-nak, hogy „a pontos építészeti funkcionális részletek kevesebbet számítanak, mint az összbenyomás"70

A viszonylag ritkán előforduló egész alakos emberábrázolások - amilyenek Trimalchio sírján is álltak - egyik lehetséges magyarázata, hogy a libertini ilyen módon utánozták a római arisztokraták lépten-nyomon megtalálható portrészobrait. ${ }^{71}$ Mivel a libertini egyik legfontosabb joga a törvényes házasságkötés volt, a férfiakat leggyakrabban hagyományos fehér togában, a nőket pedig pudicitiát sugalló tartással és annak kellékeivel (például fátyollal), illetve a dextrarum iunctio gesztusával ábrázolták. ${ }^{72}$ Petronius szövegéből ugyanakkor nem derül ki, hogy pontosan milyen típusú (például oltár vagy aedicula) síremlékről lehet szó. Ami Trimalchio és Fortunata szobrát illeti, ezek szembeötlő bizonyítékai annak, hogy a „giccsművészet” már az ókori Rómában is tombolt a temetőkben. Trimalchio szobrának talapzatán az elmaradhatatlan kiskutya, koszorúk és kenőcsösedények mellett a gladiátorsztár Petraites viadalai lettek volna kifaragva. Itt ugyanazt a jelenséget figyelhetjük meg, mint korábban a hajórakománnyal kapcsolatban: Petronius célja az össze nem illöségen keresztül Trimalchio parvenüségének bemutatása volt. Tény, hogy az ölebek tartása Rómában is divatozott: Iuvenalis epés megjegyzése szerint a nők szívesebben küldenék a férjüket a sírba, ha ezzel megmenthetik kis kedvencüket (Sat. VI, 653, 4: catellae). Seneca szatírája szerint még Claudiusnak is volt egy kutyája, akit simogatni szokott (Apoc. 13: subalbam canem in deliciis habere adsueverat). A kutyákat gyakran temették díszes sírokba, esetleg gazdáik mellé. Az ölebekre írt sírepigrammák is divatosak voltak - se szeri, se száma ezeknek a különféle antológiákban -, bár sokakban nyilván ugyanolyan ellenérzést is kiválthattak, mint manapság a házi kedvencek temetői: „Kérlek, ne nevess, ha ez kutya sírja...” - mondja egy Firenze mellett talált görög nyelvű sírvers (EG 627 Kaibel: $\mu \eta \dot{\text {, } \delta \varepsilon ́ o \mu \alpha l, ~ \gamma \varepsilon \lambda \alpha ́ \sigma \eta \varsigma, ~ \varepsilon i ~ \kappa v v o ́ \varsigma ~}$

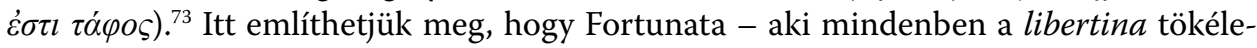

69 J. Bodel: Trimalchio's Underworld. In: The Search for Ancient Novel. Ed. J. Tatum. Baltimore 1994. $241-243$

70 Hope: i. m. (61. jegyz.) 148.

71 V. Kockel: Porträtreliefs stadtrömischer Grabbauten. Mainz 1993; B. C. Ewald: Funerary Monuments. In: The Oxford Handbook of Roman Sculpture. Eds. E. A. Friedland - M. G. Sobocinski-E. K. Gazda. Oxford 2015. 390-406.

72 P. Zanker: Grabreliefs römischer Freigelassener. JDAI 90 (1975) 267-315, különösen 289-291; Kockel: i. m. (71. jegyz.) 25-31, 35-53.

73 A. T. Jennison: Animals for Show and Pleasure in Ancient Rome. Manchester 1937; F. D. Lazenby: Greek and Roman Household Pets. CJ 44 (1947) 245-252, 299-307. 
tes típusalakja ${ }^{74}$ - szintén két házi kedvenccel van ábrázolva: egyik kezében galambot tart, a másikkal pórázon kiskutyát vezet. (Vagyis a házaspár közötti dextrarum iunctio gesztust ebben az esetben nyugodtan ki is zárhatjuk.) A columba egyébként inkább a gyermekek sírjaira jellemző ábrázolás, miközben tudjuk, hogy Fortunata már nem volt fiatal a regény dramatikus időpontjában. ${ }^{75}$ John Bodel Fortunata szobrának venusi vonásait emelte ki. ${ }^{76}$

A Cena Trimalchionis és a gladiátorviadalok kapcsolatát már több tanulmány is részletesen elemezte. ${ }^{77}$ Petraites kétszer említett neve $(52,3 ; 71,6)$ mellett szerepel még a vele kortárs Prudensé is $(52,3)$, akinek egyik viadalát egy pompeii falfirkán is megörökítették rajongói (CIL IV 538 = ILS 5138). Petraites és Prude(n)s, valamint Orie(n)s és Calamus neve emellett számos használati tárgyon is szerepel, amelyek a Birodalom nyugati felében kerültek elö. ${ }^{78}$ Henry T. Rowell arra is jogosan hívta fel a figyelmet, hogy Trimalchio imádott sztárjának valamennyi viadalát (omnes pugnas) meg akarta örökíttetni szobrának talapzatán, ami azt is jelenti, hogy ezek a birodalomszerte körülrajongott csillagok viszonylag kevésszer szerepeltek a porondon.

Ám ezzel még korántsem fejezhetjük be Trimalchio síremlékének tárgyalását. A szobor mellett - a parvenü nouveau riche elképesztő ízléstelenségének újabb példájaként - ott találjuk fiúszeretőjének (cicaro) szobrát is. Trimalchio olyan ostoba, hogy a síremlékére valószínűleg szintén kőből kifaragtatott amforákat begipszelt kiöntőnyílással ábrázoltatja, hogy „ki ne folyjék belölük a bor”. (Az nem valószínű, bár nem is lehetetlen, hogy valódi borral teli amforákat tétetett volna a sírjára.) Ami a törött amforán

${ }^{74}$ M. B. Skinner: Fortunata and the Virtues of Freedwomen. In: Narrating Desire: Eros, Sex, and Gender in the Ancient Novel. Eds. M. P. Futre Pinheiro - M. B. Skinner - F. I. Zeitlin. Berlin - Boston 2012. 199-210.

75 Az állatkedvencek tartásáról általában lásd L. Bodson: Motivations for Pet-Keeping in Ancient Greece and Rome: a Preliminary Survey. In: Companion Animals and Us: Exploring the Relationships Between People and Pets. Eds. A. L. Podberscek - E. S. Paul - J. A. Serpell. Cambridge 2000. 27-41.

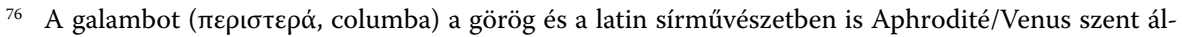
lataként értelmezik, ekként szexuális tartalmú utalásnak tartják, lásd D. B. Thompson: A Dove for Dione. In: Studies in Athenian Architecture, Sculpture and Topography: In Honor of Homer A. Thompson. Princeton 1982. 155-162. Fortunata szobrával kapcsolatban lásd Bodel: i. m. (69. jegyz.) 243.

77 H. T. Rowell: The Gladiator Petraites and the Date of the Satyricon. TAPA 89 (1958) 14-24; C. Saylor: Funeral Games: The Significance of Games in the Cena Trimalchionis. Latomus 46 (1987) 593-602; M. Kleijwegt: The Social Dimensions of Gladiatorial Combat in Petronius' Cena Trimalchionis. Groningen Colloquia on the Novel 9 (1998) 75-96; J. Bodel: Death on Display: Looking at Roman Funerals. In: The Art of Ancient Spectacle. Eds. B. Bergmann - C. Kondoleon. New Haven - London 1999. 259-281; V. Hope: Fighting for Identity: the Funerary Commemoration of Italian Gladiators. BICS 44 (2000) 93-113.

78 1892-ben Sopronban (Scarbantia) is előkerült egy üvegpohár, amelyen a négy gladiátor neve szerepelt (CIL III 14374 = AE 2013, 1223). A tárgyat Zettl Gusztáv soproni szeszgyáros vásárolta meg, akinek Bécsben élő leszármazottjai 1957-ben a Sotheby’s aukciós cégen keresztül egy amerikai milliomosnak adták el. Jelenleg a New York-i Corning Museum of Glass-ban őrzik, lásd Mráv Zs.: Scarbantia és territoriuma római felirataihoz I. In: Felirattani újdonságok 2013-ban. Szerk. Kovács P. - Fehér B. Budapest 2013. 126-146, különösen 137, Nr. 2. A „Gladiatorenbecher” témájához összefoglalóan lásd M. Papini: Munera gladiatoria e venationes nel mondo delle immagini. Roma 2004. 
sírdogáló fiút illeti, korábban már esett szó egy felesleges coniecturáról, ami miatt a szöveget legtöbben úgy értelmezik, mintha ott egy halotti urna felett síró rabszolgafiúról lenne szó. Ez minden bizonnyal a modern klasszicista sírmüvészet hatása lehet, amelynek se a regényhez, se a római kori sírművészethez nincs köze.

A felszabadítottak meglehetősen „vulgáris és magamutogató” művészeti stílust hagytak maguk után úgy a lakásaikban, mint a síremlékeiken. ${ }^{79}$ Viszont kétségkívül büszkék voltak foglalkozásukra, amely többnyire a meggazdagodás forrását is jelentette számukra: Eurysaces a kenyérkészítés munkafolyamatait, a Secundiniusok a textilkereskedelem fázisait mutatták be síremlékükön, míg a pompeii Vettiusok házának freskóin az illatszerkészítés titkait örökítették meg (Berufsdarstellungen). Trimalchio azt kéri építészétől, hogy készítsen síremlékének homlokzatára naves ... plenis velis euntes, minden bizonnyal saját egykori flottájára emlékeztetendő. Már Friedländernek is feltűnt a pompeii C. Munatius Faustus és Naevolia Tyche síremlékével való rokonság, amelyen egy kibontott vitorlájú hajó látható ${ }^{80} \mathrm{~A}$ sort hasonló ostiai ábrázolásokkal is kibővíthetnénk. ${ }^{81} \mathrm{~A}$ hajó ugyanakkor az egyik legismertebb funerális ábrázolás is a görög-római kultúrkörben. ${ }^{82}$

Trimalchiónak azonban még mindig akad ötlete: saját magát is ábrázoltatja egy domborművön, amint egy bírói emelvényen ül (me in tribunali sedentem) bíborszegélyü togában (praetextatum) öt aranygyürüvel az ujjain (cum anulis aureis quinque), amint éppen egy zsákból pénzt szór az emberek közé (nummos in publico de sacculo effundentem). Egy ünnepi lakomát (epulum) is ki akar faragtatni, a lakomázáshoz szolgáló heverőkkel (triclinia) és a rajtuk enyelgő emberekkel. Úgy tűnik, a jelenettel több probléma is akad. A tribunal eredetileg egy olyan emelvény volt, amelyen ülve a praetor szokott bíráskodni; a toga praetexta pedig a consulok, praetorok és papok kiváltságjelvényének számított. Az aranygyürü viselésének joga (ius anuli aurei) eredetileg csak a magas katonai rangban szolgáló lovagokat illette meg, de később az ordo equesterhez tartozó tartományi kormányzók is megkapták. ${ }^{83}$ Különleges megtiszteltetésként a császárok egyénileg is adományozhatták, például Augustus orvosának, Antonius Musának

79 L. H. Petersen: The Freedman in Roman Art and Art History. Cambridge 2011. 11. A foglalkozások megjelenítése a libertinusok sírábrázolásain: M. George: Social Identity and the Dignity of Work in Freedmen's Reliefs. In: The Art of Citizens, Soldiers and Freedmen in the Roman World. Eds. E. D'Ambra - G. P. R. Métraux. Oxford 2006. 19-29; L. Larsson Lovén: Roman Family Reliefs and the Commemoration of Work: Texts, Images and Ideals. In: Families in the Imperial and Late Antique Roman World. Eds. M. Harlow - L. Larsson Lovén. London - New York 2012. 141-156.

${ }^{80}$ V. L. Campbell: The Tombs of Pompeii: Organization, Space, and Society. New York - London 2015. 128-132. Egyértelműen kimondja, hogy a hajó (egy corbita) nem hordoz szimbolikus jelentést, hanem az elhunyt foglalkozására utal, contra A. Petrovic: Under Full Sail: Trimalchio's Way into Eternity. A Note on Petr. Sat. 71, 9-10. AAAHung 45 (2005) 85-90.

81 R. Meiggs: Roman Ostia. Oxford 1973. Plates 26b; 28a; 34a.

82 I. Pekáry: Repertorium der hellenistischen und römischen Schiffsdarstellungen. Münster 1999.

83 A ius anuli aurei és a szabadosok kapcsolatához lásd $A$. M. Duff: Freedmen in the Early Roman Empire. Cambridge 1958. 214-220. A visszaélésekről általában lásd M. Reinhold: Usurpation of Status and Status Symbols in the Roman Empire. Historia 2-3 (1971) 275-302. 
vagy barátjának, Vedius Polliónak (Cassius Dio LIII, 30; LIV, 23). A Kr. u. 24-ben kiadott Lex Visellia büntette azokat a felszabadítottakat, akik az ingenuitas jelvényeit jogtalanul birtokolták (CJ IX. 21; X. 32; XI. 31). A gyakorlat mégsem maradt abba, hiszen Claudius 400 libertinust fosztott meg minden vagyonuktól, mert visszaéltek a lovagrend kiváltságaival (Plin. NH XXXIII, 8). Hadrianustól kezdve azonban mégis annyira elharapódzott a szokás, hogy a császár megengedte azoknak a dominusoknak, akik rendelkeztek a ius anuli aureivel, hogy az aranygyürü-viselésnek jogát is átadhassák felszabadítottjaiknak (Dig. XL, 10, 6, 3-4). Ami pedig a gyürűk számának szaporítását illeti, erről Martialisnál olvashatunk vicces eseteket: egy ember minden ujján hatot hordott (Epigr. XI, 59), míg egy másik akkora méretű gyűrüt tett az ujjára, hogy azt ajánlották neki: inkább viselje a lábán (Epigr. XI, 37).

Trimalchio síremlékének epulumjelenetét is többen elemezték már, ennek ellenére ezzel kapcsolatban is elég sok a kérdőjel. ${ }^{84}$ Mindenekelőtt magának a szónak a jelentése: vajon az epulum a colonia minden polgára számára (plebs vagy populus) adott ünnepi lakomát jelentett, vagy csak az Augustalis-testület tagsága lehetett jelen? Ráadásul a latin szöveg is homályos: az epulum dedi binos denarios $(71,10)$ egyaránt jelentheti azt, hogy „fejenként két-két denariust érö lakomát adtam”; de akár azt is, hogy „a lakoma során mindenkinek két-két denariust adtam”. Érdekes, hogy egy Forum Sempronii-ben előkerült II-III. századi feliraton hasonlóképpen fogalmaznak: epulum dedit decurionibus singulis HS XXX sex viris et Augustalibus singulis HS XII plebi singulis HS IIII. ${ }^{85}$ John F. Donahue, megvizsgálva a principátus korából fennmaradt 133 epulumfeliratot, megállapította, hogy azon általában 2-8 sestertius között adtak készpénzajándékot (sportula). Trimalchio tehát az általa juttatott két denariusszal (vagyis 8 sestertiusszal) a felső határt célozta meg. A másik problémás eset a triclinium szóval kapcsolatos, amely - mint azt a fordításokkal kapcsolatban már tárgyaltuk - egyaránt jelenthet lakomatermet és lakomázáshoz használt heverőt, esetleg asztalt. Ezek számát illetően alighanem Caesar vitte el a pálmát, aki Kr. e. 46-ban diadalmenete tiszletetére 22000 tricliniumot állított fel Rómában (Plut. Caes. 55, 2). Arról is esett szó korábban, hogy a sibi suaviter facientem esetleg sikamlós dolgokra is utalhat, amelyhez természetesen mindkét nem jelenlétére szükség volt a lakomán. Donahue kutatásai szerint előfordul ugyan, hogy utriusque sexus képviselőit meghívják a bankettre, ennek említése azonban oly ritka, hogy föltétlenül a főszabály alóli kivételnek kell tekintenünk. ${ }^{86}$

Végül elérkeztünk Trimalchio síremlékének utolsó eleméhez, a napórához (horologium), amelynek számos fajtáját számon tartja a kutatás, és méretük is igen különböző

84 P. Perrochat: Pétrone: Le festin de Trimalcion: commentaire exégétique et critique. Paris 1962. 71; J. F. Donahue: Euergetic Self-Representation and the Inscriptions at Satyricon 71.10. CPh 94 (1999) 69-74.

85 CIL XI 6117, idézi Donahue: i. m. (84. jegyz.) 72.

86 Például epulo diviso utriq(ue) sexui, AE 1966, 183; epulo dato utriusq(ue) sexus, CIL II 1267, ua. 1378; populo utrius[que] / sex\{s\}us(!) |(denarios) C et e[pulum] / biduo ded[it], CIL IX 981, plebei urban[ae] / utriusque sexus / crustu[l]um et mulsum / dederunt, CIL IX 3954; municipibus et incolis utriusque sexus / epulum et HS IIII(milia) n(ummum), CIL XI 5693. 
lehetett, a hatalmas obeliszkektől a hordozható eszközökig. ${ }^{87}$ Egyébként Trimalchio sírján a horologium igazi célja sem az idő mutatása, hanem az elhunyt nevének hirdetése lett volna. Szintén feliratokról tudjuk, hogy a nagyobb méretü napórákat padokkal is ellátták, nyilván azért, hogy az arra járók - ha kedvük szottyan rá - azokon megpihenve a földi élet rövidre szabott idejéről elmélkedhessenek. ${ }^{88} \mathrm{Ez}$ a gondolat lépten-nyomon felbukkan a horologiumok feliratain, ${ }^{89}$ és bizonyára Trimalchio eredeti szándékától sem állt távol, aki „napórát és betanított kürtöst tart az ebédlőjében, hogy mindig tudja, mennyit vesztegetett el az életéből” (HIK). ${ }^{90}$ A napóra természetesen másra is emlékeztetett: például a 6-10. órát a számlapon gyakran a ZH@I szóval jelölték, vagyis ekkor lehetett kirúgni a hámból.

\section{Trimalchio sírfelirata}

A síremlékek vizuális dimenzióját egészítették ki a sírfeliratok a verbalitás dimenziójával. Az epitáfiumok szövegei erőteljes képi üzenetbe voltak beágyazódva, és a kettő folyamatos kölcsönhatásban állt egymással. ${ }^{91}$ Greg Woolf szerint az illitterátus emberek akár egyfajta pictogramként is olvashatták a feliratokat, mivel azok textusát erőteljesen rövidítették. ${ }^{92}$ Talán erre is utalhat Trimalchio egyik régi rabszolgatársának, Hermerosnak a megjegyzése: „a kőbe vésett betűket ismerem” (58, 7: lapidarias litteras scio). Mintha ma azt mondaná valaki: csak a nyomtatott nagybetüket tudja olvasni. ${ }^{93}$

87 R. J. A. Talbert: Roman Sortable Sundials. The Empire in Your Hand. Oxford 2017. Howell: i m. (57. jegyz.) 40. Síremlékbe épített napórára a szerző a Via Labicana mellett álló ismert columbarium feliratát hozta fel párhuzamnak (CIL VI 10237 = ILS 7870 = CLE 371), amelyben látszólag valóban sok a közös elem, viszont nem szabad figyelmen kívül hagynunk, hogy ez utóbbi esetben közös sírról van szó.

88 Például in honorem / [[Neronis]] Claudi / Caesaris Augusti / Germanici / Sex(tus) Paeticus Q(uinti) f(ilius) / Tertius et / Sex(tus) Paeticus Sex(ti)f(ilius) / Firmus / horologium cum sedibus / Paganis Laebactibus / dederunt (CIL V 2035 = ILS 5622, Pagus Laebactium [Castellavazzo], Kr. u. 54-68).

89 CIL II 1685; III 1070, 1276; V 2035 etc.; CIG 1947, 6179. A napórákhoz társított epigrammák ugyanezt a szemléletet tükrözik: AP IX 780, 806, 807; X 43, lásd H. H. Davis: Horologium and Symbolism. Classical Weekly 49 (1956) 69-70.

90 Sat. 26, 9: horologium in triclinio et bucinatorem habet subornatum, ut subinde sciat quantum de vita perdiderit. (A horologiumot számomra kideríthetetlen okból Révay József vízórának fordította, pedig azt latinul is clepsydrának hívták, lásd Sen. Epist. 24, 20.)

91 M. Corbier: Lécriture dans l'image. In: Acta Colloquii epigraphici Latini: Helsingiae 3-6. Sept. 1991 habiti. Eds. H. Solin - H. O. Salomies - U. Lierz. Helsinki 1995. 113-162; M. Koortbojian: In commemorationem mortuorum: Text and Image along the 'Street of Tombs'. In: Art and Text in Roman Culture. Ed. J. Elsner. Cambridge 1996. 210-233.

92 G. Woolf: Monumental Writing and the Expansion of Roman Society in the Early Roman Empire. JRS 86 (1996) 22-39, különösen 28; cf. M. Corbier: L'écriture en quête de lecteurs. In: Literacy in the Roman World. Ed. J. H. Humphrey. Ann Arbor 1991. 99-118.

93 P. Veyne: A History of Private Life from Pagan Rome to Byzantium. Transl. by A. Goldhammer. Cambridge (Mass.) - London 1987. 18 szerint ez azt jelentette, hogy az illető nem volt képes a kurzív írást elolvasni, vagyis a könyvek egy részét és a magánlevelezéseket sem. A portásfülkénél látható CAVE CANEM feliratot is „négyszögletes”, azaz álló nagybetűkkel írták (Sat. 29, 2: quadrata littera scriptum). 
Trimalchio azt akarja, hogy síremlékén ante omnia a funerális epigráfiában szokásos $H($ oc) M(onumentum) H(aeredem) N(on) S(equitur) legyen felvésve, ami azért is rendkívül szokatlan, mivel ezt a szöveget általában a feliratok záróformulájában szokás használni. ${ }^{94}$ De mit is jelent ez a $H M H N S$ formula, és vajon mire utalhatott ezzel Petronius? ${ }^{95} \mathrm{~A}$ hagyományos magyarázat szerint a regény kontextusában ezt kell értenünk rajta: „Ez a sír nem képezi részét azon birtokoknak, amelyeket örököseimre hagyok, a halálom után továbbra is az én birtokomban marad, ugyanúgy, ahogyan a lakóhelyem is az én birtokomban volt, amíg éltem." ${ }^{\text {A }} \mathrm{A}$ formula Horatius szatíráiban is feltűnik: „Rég ide hordta a szolga a társának tetemét egy / ócska faládában, ha kidobták szűk odujából; / köztemetőnek használták a szegények e telket / s Pantolabus, a bohóc, meg Nomentanus, a korhely, mert a cövek kijelölte ezer láb hosszan elől és / háromszáznyira kétoldalt: „Örököst ne kövessen / síroszlop!«" (Serm. I, 8, 10-13. Horváth István Károly fordítása). Ebben a szövegösszefüggésben azért humoros a $H M H N S$ formula feltüntetése, mivel ez a szegények használatára kialakított közös sír (commune sepulchrum) volt. Csakhogy Trimalchio esetében Charles Christopher Mierow szerint nem érvényes a hagyományos magyarázat, mivel a res sacrae körébe tartozó síremlékek a római jog szerint eleve nem képezhették öröklés tárgyát (nullius in bonis). A jogi szövegek tanúsága szerint ez a formula arra vonatkozott, hogy a sír készítőjének halála után nem lehetett mást beletemetni a sírba. Fentebb ezért fordítottam így: „Ez a síremlék nem lehet örökösé.”

A bevezetésben szó esett arról, hogy a Trimalchio cognomen minden bizonnyal szír eredetű. A cena házigazdája egyébiránt rendkívül büszke nevére: azt nemcsak síremlékén szerepelteti, hogy „ha akarja valaki, ha nem, elolvassa” $(71,12)$, hanem kétszer van felírva az ebédlőterem ajtófélfáira $(30,2 ; 30,4)$, és táljaira is rá van vésve $(31,10)$. A Gaius Pompeius Trimalchio Maecenatianus név azt feltételezi, hogy egykori gazdáját Gaius Pompeiusnak hívták. ${ }^{97}$ (A helyes névalak természetesen a Gaius Pompeius Gaii libertus Trimalchio lett volna, de Trimalchio nem tartotta fontosnak, hogy felszabadí-

94 Szövegvariánsok: H(ic) L(ocus), H(ic) L(ocus) S(epulturae), H(ic) L(ocus) et M(onumentum); $A($ d) $H$ (aeredem) $N($ on $) P$ (ertinet). Rómában a szokásos formula így hangzott: $H$ (uic) M(onumento) D(olus) M(alus) $A$ (besto), ami egyértelműen a síremlék védelmét szolgálta a rongálók ellen. $M$. Carroll: Spirits of the Dead: Roman Funerary Commemoration in Western Europe. Oxford 2006. 79-80.

95 Cf. Mommsen: i. m. (61. jegyz.) 116: „Da ist zunächst die bekannte Formel hoc monumentum heredem non sequatur, wofür eigentlich sequetur oder allenfalls sequitur erfordert wird; aber so genau nimmt es Trimalchio mit der technischen Formel nicht. Natürlich versteht er sie noch viel weniger; er sieht darin nicht die Anordnung, dass die Grabstätte mit Ausschluss der Familie nicht angehörigen Erben der Descendenz verbleiben soll, was ja auch ganz richtig ist, aber doch nicht gerade ante omnia eingeschärft zu werden braucht."

96 C. C. Mierow: Hoc Monumentum Heredem Non Sequitur. An interpretation. TAPA 65 (1934) 163-177, különösen 164. A formula elöfordulásait összegyüjtötte és elemezte: A. G. Valdecasas: La fórmula HMHNS en las fuentes epigráficas romanas. Anuario de historia del derecho español 5 (1928) 5-82.

97 C. Kunst: Identität und Unsterblichkeit: Zur Bedeutung des römischen Personennamens. Klio 81 (1999) 156-179; H. Solin: Petron und die römische Namengebung. In: Petroniana. Gedenkschrift für Hubert Petersmann. Hrsgg. J. Herman - H. Rosen. Heidelberg 2003. 193-199. 
totti státuszáról is megemlékezzen. ${ }^{98}$ ) A rabszolgák az egész házban hangosan kiáltozzák praenomenjét: Gaio feliciter (50, 1), ave Gai... vale Gai $(74,8)$. Az előnéven szólítás az ókori Rómában a bizalmas kapcsolat jele, és Horatius is kiemeli, hogy a libertinusok mennyire odavannak attól, ha ezen szólítják őket: gaudent praenomine molles auricolae (Hor. Sat. II, 5, 32).${ }^{99}$ Bár a Pompeius gentilicium rendkívül gyakori a libertinusok körében az I-II. században ${ }^{100}$ - magában a Cena Trimalchionisban is szerepel egy C. Pompeius Diogenes $(38,10)$-, nem zárhatjuk ki, hogy - akárcsak a Maecenatianus adnomen esetében ${ }^{101}$ - itt is irodalmi játékról van szó. Szinte bizonyosra vehető, hogy itt nem csupán Trimalchio adakozó kedvére utal Petronius, hanem a történeti Maecenas elé is görbe tükröt tart, mivel több elemző szerint főszereplőjének karaktere (például irodalmi ízlése) több hasonlóságot mutat Augustus tanácsadójának karakterével. ${ }^{102}$

A római sírfeliratok kötelező eleme a magistratusok felsorolása. Trimalchio fiktív sírfeliratán két nehezen értelmezhető kifejezésbe is belebotlunk: az egyik a seviratus, a másik a decuria. ${ }^{103}$ Kezdjük az előbbivel. Az Augustalisokkal kapcsolatban Anton von Premerstein még a XIX. században dolgozott ki egy elméletet, amely hosszú életünek bizonyult. Szerinte a seviri Augustales, az Augustales és a seviri három különböző testületet alkottak. A három közül csak az első kettő vett részt a császárkultuszban: a seviri Augustales hatfős testület volt, amelyet évente újraválasztottak, míg az Augustales egy olyan collegium, amely állandó tagsággal rendelkezett. A két kultusztestület középpont-

98 P. Veyne: Trimalchio Maecenatianus. In: Hommages à Albert Grenier 3. Ed. M. Renard. Bruxelles 1962. 1619-1962, különösen 1624 érdekes, de nem eléggé megalapozott véleménye szerint Trimalchio első tulajdonosa Maecenas volt, akitől C. Petronius vásárolta meg. A -ianus képzővel létrehozott pseudocognomenek pedig ebben az időben egyértelműen árulkodtak viselöjük servilis eredetéről. M. Tarpin: Trimalchio Maecenatianus. La lettre de Pallas 3 (1995) 15 tette közzé a Maecenatianus néven feliratokról ismert személyeket, akik valamennyien Augusti libertusok voltak. A szerző szerint ennek a cognomennek a használata mentesítette Trimalchiót a libertinus voltára történő explicit utalás alól. Ugyanakkor Tarpinnak nincs igaza abban, hogy Trimalchio Augusti libertus volt.

99 Cf. J. N. Adams: Conventions of Naming in Cicero. CQ 28 (1978) 145-166, különösen 150.

100 [C]n(aeus) Pompeius Cn(aei) l(?)(ibertus) (AE 1983, 83, Roma, Kr. e. 31-Kr. u. 30); Cn(aeus) Pompeius / Epirus (AE 1984, 193, Napoli, Kr. u. 31-70); Cn(aeus) Pompeius Epiri l(ibertus) / Blastus (AE 1984, 228, Pompeii, Kr. u. 40-41); [L(ucius) Pompeius] Aug(ustae) lib(ertus) Fortunatus (AE 1978, 42, Roma, Kr. u. 131-170); Pompeia / Tryphosa fecit / Sex(to) Pompeio Apol/lonio patrono suo (AE 1986, 736, ismeretlen); M(arcus) Pompeius / Felix et Pompe/ia Athenais pa/trono (AE 1971, 130, Roma, Kr. u. 71-130); Q(uintus) Pompeius / Q(uinti) l(ibertus) Pericles (AE 1971, 53, Roma) etc.

101 P. Grimal: Sur quelques noms propres de la Cena Trimalchionis. Revue de Philologie, de Littérature et d'Histoire Anciennes 16 (1942) 161; G. Schmeling: The Literary Use of Names in Petronius Satyricon. Rivista di Studi Classici 17 (1969) 5-10.

102 Veyne: i. m. (98. jegyz.) 1617-1624; B. Baldwin: Trimalchio and Maecenas. Latomus 43 (1984) 402-403; J. F. Makowski: Iocosus Maecenas: Patron as Writer. Syllecta Classica 3 (1992) 25-35; H. Petersmann: Maecenas, Nasidienus, und Trimalchio. In: Candide Iudex: Beiträge zur augusteischen Dichtung. Festschrift für Walter Wimmel zum 75. Geburtstag. Hrsg. A. E. Radke. Stuttgart 1998. 269-277; S. N. Byrne: Maecenas and Petronius' Trimalchio Maecenatianus. Ancient Narrative 6 (2007) 31-50.

103 Sat. 71,12: huic seviratus absenti decretus est cum posset in omnibus decuriis Romae esse tamen noluit. Ezekben a kérdésekben természetesen nagyon is van értelme a fennmaradt epigráfiai anyag összehasonlító vizsgálatának. 
jában is más-más állt: a seviri Augustales Augustus személyének, az Augustales pedig a gens Iuliának vallási tiszteletét szervezte. Lily Ross Taylor ezt azzal módosította, hogy az Augustales és a seviri Augustales csak Traianus idejében szerveződtek testületekké (corpora, collegia, ordines). Robert Duthoy a 70-es években az addig előkerült epigráfiai anyag részletes vizsgálata után jutott arra a következtetésre, hogy a seviri és a seviri Augustales megjelölés valószínüleg ugyanarra a testületre vonatkozik, amelynek tagságát évente választották, és a summa honoraria befizetése után lehetett valaki tagja, bár előfordulhatott, hogy valakit tiszteletbeli taggá (ob honorem) választottak, és éppen Petronius szövege utal rá, hogy a Hermeros nevü gazdag felszabadított ingyen lett a testület tagja (57, 6: sevir gratis factus sum). Andrik Abramenko a 90-es években azzal hozott újat a kutatásban, hogy a három eddig külön kezelt intézményt ugyanannak a testületnek látta, amely az itáliai városokban az ordo decurionum mögött egyfajta quasi-ordót képviselt, amely ugyan sohasem vált olyan rendes ordóvá, mint a lovagrend a senatori rend mögött. Az Augustalisok közé olyan libertini vagy ingenui kerültek be, akik nem fértek be a városok szűkre szabott decuriotestületeibe. ${ }^{104}$ Ittai Gradel a XXI. század elején ugyanakkor már azt is kétségbe vonta, hogy az Augustalisok egyáltalán részt vettek-e a császárkultuszban. ${ }^{105}$ Szerinte ez egy magántestület volt, és puszta véletlen, hogy az Augustalisok többsége a császároknak ad tiszteletet feliratain, hiszen Augustus korától kezdve természetes, hogy a nyilvános feliratok többsége a császárnak szóló tiszteletadással kezdődik. (Amit ugyan Trimalchio sírfeliratán hiába is keresnénk.) Legutóbb Henrik Mouritsen adott hangot annak a véleményének, hogy az Augustales nem képezett külön ordót, és elsősorban nem is a császárkultuszban játszott szerepet, hanem fö tevékenysége az euergetizmus volt. ${ }^{106}$ (Amit valóban megtalálunk Trimalchio síremlékén és sírfeliratán is.)

Ami a „helyet foglalhatott volna Róma bármelyik decuriájában, de nem akarta” $(71,12)$ szöveget illeti, ebben még tanácstalanabb a kutatás. ${ }^{107}$ A kortárs olvasóban nyilván az keltett elsősorban vicces hatást, hogy Trimalchio, a „vidéki” parvenü pénze révén akár valamelyik római „service club” - ez Gilbert Bagnani kifejezése ${ }^{108}$ - tagjává is válhatott volna. Az angol klubrendszerrel való összehasonlítás szellemes ugyan, de nem mond semmit a római valóságról. Tacitustól tudjuk, hogy Claudius idejében már anynyira kiterjedt volt „a libertinusok gyülekezete” (late fusum id corpus), hogy a senatusban ellenintézkedéseket követeltek. A védelmükre kelők azonban így érveltek: „ez adja

104 A felszabadítottak részvételéről a decuriotestületekben, illetve ezek síremlékeiről Ostiában és Pompeiiben lásd H. Mouritsen: Freedmen and Decurions: Epitaphs and Social History in Imperial Italy. JRS 95 (2005) 38-63.

105 I. Gradel: Emperor Worship and Roman Religion. Oxford 2002. 229-230.

106 H. Mouritsen: The Freedmen in the Roman World. Cambridge 2011. 250.

107 Az alábbi gyűjtésben Szabó Ernő, a PTE Interdiszciplináris Doktori Iskola hallgatója nyújtott hasznos segítséget, amiért ezúton is köszönetemet fejezem ki. B. Severy-Hoven: The Satyrica of Petronius. An Intermediate Reader with Commentary and Guided Review. Norman 2014. 151. A szerző állítása szerint Trimalchio sírfeliratának ezen sorához nem létezik epigráfiai párhuzam.

108 G. Bagnani: Trimalchio. Phoenix 8 (1954) 77-91, különösen 89. 
a legtöbb tribust, decuriát, a polgári és papi tisztségek segédszemélyzetét, a városban toborzott cohorsokat is, és a legtöbb lovag, igen sok senator sem máshonnan vezeti le származását."109 Theodor Mommsen szerint ilyen „segédhivatalnok” (apparitor) lehetett volna Trimalchio is Rómában, ha akarta volna. ${ }^{110}$ Ezt a véleményt a legtöbb modern kommentátor is átvette. ${ }^{111}$ Pedig azt a lehetőséget is meg kellene fontolni, hogy Petronius esetleg collegiumi decuriára utalhatott. A fabri tignuarii ostiai collegiumának Kr. u. 198-ból datálható albuma 331 tagot sorol fel, akiket 16 decuriába osztottak (CIL XIV 4569). A legnagyobb római collegium is a fabrum tignariorum volt, amely 60 decuriából állt, egyenként 22 taggal. A decuriákat számozták, és közöttük egyértelműen komoly presztízskülönbségek voltak. Az egyes decuriáknak is voltak patronusai, magistere és decurialisai. Az egyes collegiumok élethosszát az 5 évente megtartott lustrumokban mérték, a tisztújításra is ekkor került sor. A kutatás megegyezik abban, hogy ezek az egyesületek olyan „kis világokat” képeztek a római világban, amelyek miniatűr utánzatai voltak a nobilitas nagy múltú, exkluzív és valóban tekintélyes szervezeteinek. Mindez Rómában persze még nevetségesebben hathatott, mint a libertinusoktól hemzsegő kikötővárosokban: Ostiában vagy Puteoliban. ${ }^{12}$

Trimalchio személyes tulajdonságai közül a pius „kegyes, jámbor”, a fortis „erős” és a fidelis „hűséges, megbízható” került fel a feliratra $(71,12)$. Ezeket rendszerint az arisztokraták jellemző tulajdonságaiként szokták számontartani (Vergilius is így használja őket); Marc Mayer y Olivé pedig a legiók mellékneveivel hozta összefüggésbe. ${ }^{113}$

109 Tac. Ann. XIII. 27, 2: hinc plerumque tribus decurias, ministeria magistratibus et sacerdotibus, cohortes etiam in urbe conscriptas; et plurimis equitum, plerisque senatoribus non aliunde originem trahi. Borzsák István fordítása.

110 Mommsen: i. m. (61. jegyz.) 119: „Von diesen römischen Decurien sagt also Trimalchio, der wohlhabende Mann, dass er in alle hatte gelangen können, wenn er Lust dazu gehabt hatte. Freilich hatte er dann wol seinen Wohnsitz in Rom nehmen müssen; denn die Inschriften dieser Apparitoren sind ganz überwiegend stadtrömisch und bestätigen, was an sich schon wahrscheinlich ist, dass der Inhaber eines solchen Postens, wenn auch kaum Amtsgeschäfte, doch ein Amtsdomicil in Rom hatte. Darum eben lässt der Dichter seinen Helden nicht zu dem Besitze solcher Stellungen gelangen, sondern nur ihn erklären, dass es allein von ihm abgehangen haben wurde, in der Hauptstadt eine amtliche Stellung zu bekleiden und in die öffentlichen Decurien zu gelangen." Az apparitores teljes körű feldolgozását lásd N. Purcell: The Apparitore: A Study in Social Mobility. PBSR 51 (1983) 125-173.

111 Lásd például $N$. Tran: Les membres des associations romaines. Le rang social des collegiati en Italie et en Gaules sous le Haut-Empire. Rome 2006. 228: „L'affranchi de roman, désireux de voir sa dignité de seuir gravée sur sa pierre tombale, aurait repoussé l'honneur d'appartenir une décurie d'appariteurs. Ce geste altier révélerait en creux à quel point l'association de l'augustalité et de la charge d'appariteur pouvait être naturelle."

112 J. Liu: Professional Associations. In: The Cambridge Companion to Ancient Rome. Ed. P. Erdkamp. Cambridge 2013. 352-368, különösen 362. T. Frank: The People of Ostia. CJ 9 (1934) 481-493, különösen 488 szerint Ostiában különösen sokan szerettek a sírfelirataikon collegiumtagságukkal büszkélkedni.

113 D. O. Ross: Virgil's Aeneid. A Readers Guide. Malden - Oxford 2007. 46; M. Mayer y Olivé: Los tituli presentes en la casa de Trimalción: ¿un ejemplo de uso epigráfico doméstico? SEBarc 10 (2012) 61-80, különösen 79 . 
Ami Trimalchio magánvagyonát illeti: a hátrahagyott 30 millió $(71$, 12: sestertium reliquit trecenties) önmagában ugyan soknak tűnhet, de összehasonlítva más esetekkel már egyáltalán nem olyan kirívó. Richard Duncan-Jones korai császárkori magánvagyonokról készített statisztikáiban, amelyek élén Cn. Cornelius Lentulus és Claudius szabadosa, Narcissus áll 400 milliós vagyonnal (Sen. ben. II, 27; cf. Suet. Tib. 49, 1; Dio LX, 34, 4), mindössze a huszadik helyet foglalja el Trimalchio. ${ }^{114}$ A legtöbb kommentátor egyetért abban, hogy a 30 millió „közmondásos” pénzösszeg, bár Reinhard Wolters szerint Claudius ismert orvosa, C. Stertinius Xenophon lehetett Trimalchio alakjának közvetlen mintája, aki szintén 30 milliót hagyott hátra, bár vagyonát jelentősen megcsappantották a nápolyiak javára végrehajtott középítkezései (Plin. NH XXIX, 7). ${ }^{115}$ Azonban a lényeg megint csak nem a konkrét pénzösszeg nagysága: Trimalchio világában az emberek értékét pénzzel mérik: sestertiarius homo $(45,8)$; homo dipundiarius $(74,15)$, és a jól ismert mondás: assem habeas, assem valeas $(77,6)$.

A római sírfeliratok egyik kedvelt témája az elhunyt bölcsességének és müveltségének dicsérete. Vicces, hogy Trimalchio épp ennek az ellenkezőjét hangoztatja: „filozófust sosem hallgatott" (71, 12: nec unquam philosophum audivit) - természetesen ez az értékhiány szembe van állítva az elhunyt gazdagságával. A textusnak ismert feliratos párhuzamai nincsenek: Mommsen azt a humoros megjegyzést füzte hozzá, hogy bár sok római felirat készítőjére igaz lehetett volna ez a megállapítás, ő egyet sem ismer, aki ezt be merte volna vallani. ${ }^{116}$ John Bodel szerint éppen ezek a valós feliratokról nem ismert, szokatlan elemek adnak komikus csavart a szövegnek, és emelik azt a normák fölé. ${ }^{117}$ Egyébként a műveletlenség Trimalchio világában „menő dolog”: a házigazda egyik volt rabszolgatársa, Hermeros így förmed rá a regény föszereplőjének barátjára: „Nem tanultam geometriát, kritikát és értelmetlen tudálékos hülyeségeket, de ismerem a betűket a kőtáblán, s megmondom, mennyi a rézpénz századrésze, a súlyoké és az ezüsté. Szóval, ha akarod, fogadok veled: állj a porondra, s kiteszem a pénzt! S majd megtudod, hogy édesapád hiába költekezett, akármilyen jól tudod is a rhetoricát" (HIK). ${ }^{118}$

114 R. Duncan-Jones: The Economy of the Roman Empire. Quantitative Studies. Cambridge 1982² 343. (Ö is kétségbe vonja, hogy ez a szám konkrét gazdaságtörténeti adatként használható volna.)

115 G. Bagnani: „And Passing Rich.... In: Studies in Honour of G. Norwood. Ed. M. E. White. Toronto 1952. 218-223, különösen 223; H. Kloft: Trimalchio als Ökonom. Bemerkungen zur Rolle der Wirtschaft in Petrons Satyricon. In: E fontibus haurire. Beiträge zur römischen Geschichte und ihren Hilfswissenschaften. Heinrich Chantraine zum 65 Geburtstag. Hrsgg. R. Günther - S. Rebenich. Paderborn 1994. 117-131, különösen 122; R. Wolters: C. Stertinius Xenophon von Kos und die Grabinschrift des Trimalchio. Hermes 127 (1999) 47-60.

116 Mommsen: i. m. (61. jegyz.) 120-121.

117 J. Bodel: Cena Trimalchionis. In: Latin Fiction: The Latin Novel in Context. Ed. J. B. Hoffmann. London - New York 1999. 38-51, különösen 43.

118 Sat. 58,7: non didici geometrias, critica et talogias naeniast, sed lapidarias litteras scio, partes centum dico ad aes, ad pondus, ad nummum. Ad summam, si quid vis, ego et tu sponsiunculam: exi, defero lamnam. Iam scies patrem tuum mercedes perdidisse, quamvis et rhetoricam scis. Elemzését lásd E. Best: At titudes toward Literacy Reflected in Petronius. CJ 61 (1965) 72-76; A. D. Booth: The Schooling of Slaves in First-Century Rome. TAPA 109 (1979) 11-19. 
Trimalchio egyáltalán nem terjengős feliratát rövid elköszönő formulával zárja: vale - et tu. Már Mommsen is felhívta a figyelmet arra, hogy a feliratokon valóságosan létező kifejezéssel van dolgunk (pl. viator vale / et tu, CIL V 4887,14-15; val[e] / et tu, CIL V 7838,8) -, ám itt megint nem a párhuzamok a lényegesek. Ez csupán egy nyelvi játék, amely arról szól, hogy Trimalchio beleképzeli magát a feliratát majdan olvasó ember gondolatvilágába, aki - miután elolvasta a feliratot és a köszönést - vissza fog köszönni neki, mivelhogy őt mindenki pius, fortis és fidelis embernek fogja tartani, és jóakarattal lesz iránta. Az eszébe sem jut, hogy az arra járók esetleg hasukat fogják a nevetéstől, miután meglátják a síremléket, és végigbetűzik a sírfeliratot. ${ }^{119}$ A magam részéről csak egyet érteni tudok Valerie M. Hope gondolatával, aki szerint bárhogyan is reagál valaki Trimalchio ízlésére, van abban valami humánus és érthető, ahogyan Petronius hőse hangosan elmélkedik, gyakran kételkedve és szinte egy gyermek kíváncsiságával, hogy vajon hogyan fognak majd rá halála után emlékezni. Még a sírfelirattal kapcsolatban is visszakérdezi építészét: szerinte jó lesz-e ilyen formában ${ }^{120}$

Összefoglalásképpen megállapíthatjuk, hogy a monumentum és az epitaphium Petronius hősét szinte minden létező formában megmutatja: mint paterfamiliast, rabszolgatartót, férjet, házigazdát, üzletembert, városi polgárt, tisztségviselőt, jótevőt. Petronius a síremlékek és sírfeliratok unalomig jól ismert kliséiből egy, a realitás és a fantáziavilág határán mozgó érdekes világot teremtett, amely a kommunikáció legkülönbözőbb formáit használta fel. A domborművek és szobrok vizuális információt közöltek, a felirat szövege a szemre és a fülre egyaránt hatást gyakorolt (amennyiben hangosan olvasták), a bor és a gyümölcsök az ízlelést célozták, míg a kert fái és virágai a szaglásra hatottak. Trimalchio síremléke a legkülönfélébb érzelmeket mozgatta meg: a szeretett férj, gazda és bőkezű vendéglátó elvesztése felett érzett gyász mellett ott volt a gazdagsága miatt érzett irigységgel vegyes csodálat, az élet élvezete minden lehető formában, sőt még a gladiátorjátékok iránti szenvedély is. Petronius erőteljes leírást alkotott, amelynek ha nem is vagyunk képesek valamennyi elemét pontosan a helyére illeszteni, lelki szemeink előtt mindannyian el tudjuk képzelni összhatását, amely a valóságban gyökerezik, de sohasem szűnik meg az lenni, aminek szánták: irodalom. ${ }^{121}$

\section{SUMMARY}

Trimalchio's sepulchral complex (the tomb-garden, the monument and the epitaph) has long been an object of study. This chapter of Petronius' novel $(71,5-12)$ has provoked an incredible number of scholarly books and papers either on the part of classicists or historians of ancient literature, art, society and economy. After a short recapitulation of Trimalchio's origin, career, and financial position in his contemporary society, our paper concentrates on his tomb-complex as compared to available artistic and epigraphic data. My aim is, however, not only the accumulation of comparative material, which is indeed a very useful tool for the study of linguistic, artistic, social, administrative, economic etc. phenomena, but also to look at this text as it

119

120 Hope: i. m. (61. jegyz.) 150.

121 Hope: i. m. (61. jegyz.) 149. 
is: literary fiction. The satire, to which genre this novel belongs, always uses three basic techniques in making faults and mistakes seem ridiculous: typifying, mixing, and exaggeration/diminution. Trimalchio is a typical representative of the well-off libertus by Campanian standards, but he absorbs some attributes of other Roman celebrities as well (e.g. Maecenas, Claudius, Nero etc.). Compared to other tombs known by archeologists, it is a fact that he did not possess the biggest tomb-complex in the Roman world, but probably he did have one of the tackiest and most tasteless; he did not compose the most bumptious epitaph in Latin, but this relatively short text is just foolish enough to make its contemporary readers laugh.

Keywords: Petronius, Satyricon, Cena Trimalchionis, Roman novel, satire, freedmen, Roman epigraphy, Roman sepulchral art

\section{GRÜLl TiBOR}

tanszékvezető egyetemi tanár

PTE BTK TTI Ókortörténeti Tanszék

7624 Pécs, Rókus utca 2.

grull.tibor@pte.hu 